$$
\begin{aligned}
& T \times 609 \\
& 458
\end{aligned}
$$




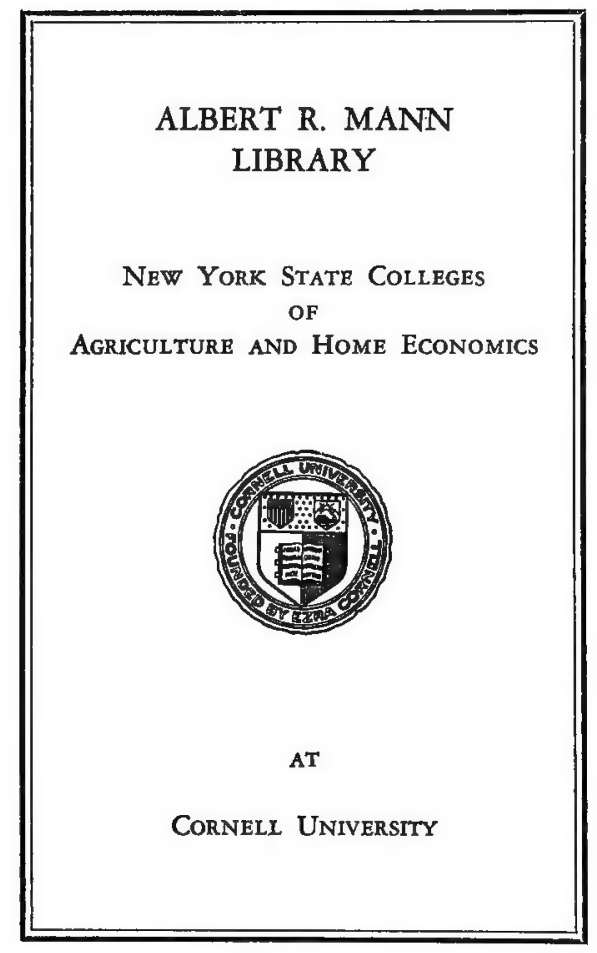

CORNELL UNIVERSITY LIBRARY

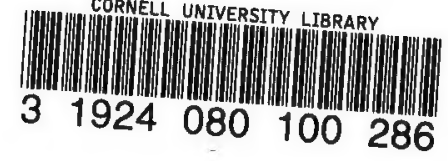




\title{
DEHYDRATION OF FRUITS AND VEGETABLES
}

\section{HEARING}

BEFORE THE

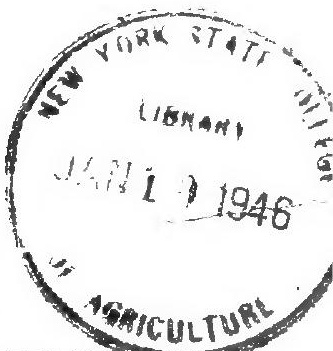

COMMITTEE ON AGRICULTURE AND FORESTKT

SUBCOMMITTEE OF THE

UNITED STATES SENATE

\section{SIXTY-FIFTH CONGRESS}

\author{
SECOND SESSION
}

ON

\section{S. 3665}

A BILL TO ENABLE THE SECRETARY OF AGRICULTURE TO ESTABLISH PLANTS IN CONNECTION WITH LAND-GRANT COLLEGES FOR THE DRYING OR DEHYDRATION OF FRUITS AND VEGETABLES, AND FOR OTHER PURPOSES

Printed for the use of the Committee on Agriculture and Forestry

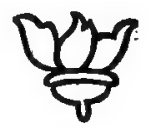

WASHINGTON

GOVERNMENT PRINTING OFFICE 


\section{COMMITTEE ON AGRICULTURE AND FORESTRY.}

THOMAS P. GORE, Oklahoma, Ohairman.

GEORGE D. CHAMBERLAIN, Oregon. ELLISON D. SMITH, South Carolina. HOKE SMITH, Georgia.

MORRIS SHEPPARD, Texas.

JOSEPH T. RANSDELL, Louisiana. WILLIAM H. THOMPSON, Kansas. ED. S. JOHNSON, South Dakota. JOHN B. KENDRICK, Wyoming.
FRANCIS E. WARREN, Wyoming. CARROLL S. PAGE, Vermont. ASLE J. GRONNA, North Dakota. GEORGE W. NORRIS, Nebraska. WILLIAM S. KENYON, Iowa. JAMES W. WADSWORTH, JR., New York. 


\title{
DEHYDRATION OF FRUITS AND VEGETABLES.
}

SATURDAY, FEBRUARY 2, 1918.

\author{
United States Senate, \\ Committee on Agriculture and Forestry, \\ Washington, D. $C$.
}

The committee met, pursuant to call at 2.30 o'clock p.m., in room No. 326, Senate Office Building, Senator Thomas P. Gore, presiding. Present: Senators Gore (chairman), Smith of South Carolina, Smith of Georgia, Sheppard, Ransdell, Gronna, and Norris.

The committee proceeded to consider the bill (S. 3665), as follows:

[S. 3665, Sixty-fifth Congless, second session.]

A BILL to enable the Secretary of Agriculture to establish plants in connection with landgrant colleges for the drying or debydration of fruits and vegetables, and for other purposes.

Be it enacted by the Scnate and House of Representatives of the United States of Amcrica in Congress assembled, That $\$ 250,000$, or so much thereof as may be necessary, is hereby appropriated, out of any moneys in the Treasury not otherwise appropriaterl, to enable the Secretary of Agriculture to establish plants for the drying or dehydration of vegetables, fruits, and other edible products, in connection with the land-grant colleges in the several States: Provided, That the Secretary of Agriculture may establish such plant at some other location in any particular State whenever in his judgment the public interest would be subserved thereby: Provided further, That the Secretary of Agriculture may, in his discretion, establish such plant in any particular state in cooperation with States, counties, municipalities, individuals, or associations not organized for profit, in which case the Secretary of Agriculture shall not pay more than one-half of the cost of establishing such plant.

The Chairmax. Mr. Horst, who will make the first statement, comes to Washington, as I understand, accredited by Gov. Stephens, of California. I believe you bring a letter from Gov. Stephens to the President?

\section{STATEMENT OF MR. E. CLEMENS HORST, SAN FRANCISCO, CAL.}

Mr. Horst. Yes, sir. Here it is.

(The letter referred to by Mr. Horst is here printed in full as follows:)

State of California, Sacramento, December $29,191 \%$.

Hon. WOODROW WILSON,

The President, Washington, D. C.

SIR: This will introduce to you Mr. E. Clemens Horst, of California, who desires to take up with you the question of drying vegetables by the people of the United States for use in their homes and by the United States Army and Navy,

I understand Mr. Horst is willing to give without charge to the Government and is willing to teach to a great number of people without any profit to himself the process of drying the vegetables which he will show you. 
The conservation of food and the supply of our people and our military forces is so vital, and Mr. Horst's ideas seem so worthy of careful investigation, that I specially request an audience for him and a careful consideration of his plans.

Very truly, yours,

WM. D. Stephens, Goternor.

Mr. Honst. This letter was presented to President Wilson by Senator McNary who gave to the President with the letter a line of a dozen or more of my dried regetables. President Wilson acknowledge the same by letter as follows:

The White House,

Washington, February 5, 1918.

Mr Dear Senator MCTARY: It was very kind and thoughtful of you to send me the dried tomatoes and mixed regetables for soup. I am looking forward with pleasure to sampling them. I am very glad indeed to see every sort of effort made for the conservation of food and this particular form of that effort interests me very much.

Cordially and sincerely, yours,

Hon. Charles L. McNary,

WOODROW WILSON.

United States Senate.

The Chatruan. What is your business, Mr. Horst?

Mr. Honst. I am a merchant and farmer and I own and operate dehydrating plants for vegetables, fruits, etc.

The Chairman. Mr. Horst, first let me say that I rould like you to state something of the effects and results of dehrdration on vegetables and fruits; something about the desirability of using dehydration in preserving vegetables and fruits; something about the history of the process, describing the process itself, and make a statement of the expense connected with the building and equipment of plants, and so forth.

Mr. Honst. The drying of regetables is a very old proposition. It was supplanted something like 30 or 40 years ago by the canning industry, and very little attention was paid to the question of drying of vegetables. The Boer war, and the Alaska excitement of 1898 , somewhat revived the industry, and a great amount of regetables were dried at that time, though the process was rather crude, but crude as it was it was successful, and the products were used then. What was left over, for instance, from the Boer war was successfully used in the present war by the British Government, and that has been after the lapse of a period of about 18 years: and $I$ cite that to show the keeping quality of the dried vegetables.

Since that time, and particularly within the last six or eight months, there has been a great deal of experimental work done on the subject of the drying of vegetables, and up to the present time the work has gone along so far that the product to-day, in my opinion, is fully equal when cooked to the fresh product, as one gets it in the city, taking, of course, into consideration that regetables, before they reach the consumer, have undergone quite a delay in handling, shipping, and rehandling, and they become aged by time; and in keeping fresh vegetables, say, from the harvest time to the consuming time in the middle of the winter is a long time, during which the vegetables more or less depreciate. The dehydrating process takes that vegetable fresh from the farm. immediately dries it, and dries it in such a way that substantially the freshness of the farm is 
preserved; and in my opinion and in the opinion also of the very finest hotels of the United States, who have made extensive trials of these recently made products, they are fully as good as fresh vegetables.

I have an abundance of letters here from a number of the finest hotels in the country-for instance, the Ritz-Carlton, of New York, and the Willard, of Washington, who have tried out the product. A number of our hotels in San Francisco are using dried vegetables in place of fresh regetables, where they have the fresh vegetables the year around.

The Chamman. Will you put those in the record?

Mr. Honst. I will, with pleasure.

(The letters referred to by Mr. Horst are here printed in full as follows :)

\section{Department of Agrtoututure,}

Bureau of Chemistry,

Mr. E. Clemens Horst,

Washington, D. C., January $25,1918$.

San Francisco, Cal.:

DEAR Sm: In response to your request for an opinion as to the value of dried vegetables, will state that we have been investigating this subject for a number of months, and find that nearly all vegetables and fruits can be dried successfully if the quality of the raw material and the methods of preparing the material for drying, the drying, and the packing of the material after drying are satisfactory. Products can be obtained which retain their distinctive properties.

The saving in containers and freight effected by drying, combined with the attractiveness of the dried products, makes us realize that we have here an industry of importance and value.

Respectfully,

Cart L. Alsherg, Chief.

Mr. E. Chemens Horst,

San Francisco, Cal.

DEAR STR: I am deeply interested in the industry of desiccated regetables and fruits. I have seen the samples of the products which you are exhibiting, and $I$ believe that the general use of such products by the general public would be highly beneficial. The rapidity at which the samples are dried and the low temperatures employed secure the full value of these products insofar as their vitamin and antiscorbutic properties are concerned.

Since vegetables and fruits contain from 80 to 95 per cent of water, the cost of transportation is enormously reduced by the use of dried products. At the same time, the dried products can be easily kept in cheap containers, and there is no danger of spoilage. In my opinion, these products are in a splendid form for use by our soldiers and sailors. They should be used in mucl larger quantities than vegetables are used at the present time for the purpose of preserving to a greater degree the health and vitality of those who eat them.

Sincerely, yours,

H. W. WILET.

THE BILTMORE,

New York, February 7, 1918.

The E. Clemens Horst Co., San Francisco, Cat.

DEAr SIRs: We have used a number. of your dried vegetables, including tomatoes, at the Biltmore, and they proved to be very satisfactory.

The results convince us that dehydration is an excellent method for preserving vegetables for use in all climates and particularly on account of the small space that is required for storage in shipment.

Very truly,

John McE. Bowman, President. 
H. Clemens Honst Co.,

San Francisco, Cal.

Ritz-Carlton Hotel,

New York, January 15, 1918.

GENTLEMEN: After trying your different dried and powdered vegetables, I take pleasure in advising you that we found them in perfectly sound condition.

If cooked properly, they are far superior in taste and more advantageous than preserved canned vegetables, as they retain all through an excellent flavor of fresh vegetables.

I can safely say I see a fine opening on the market for your useful new products.

Yours, very truly,

Albert KelLer, General Manager.

The E. Clemens Horst Co.,

Hotel Manhattan, New York, February 11, 1918.

San Francisco, Cal.

Dear SIR: After repeated trials of a variety of your dried regetables, including tomatoes, at the Hotel Manhattan, we found them very satisfactory, and are convinced that vegetables preserved in this form are admirable for use when seasonable, fresh vegetables are not obtainable.

Very truly,

P. B. Boden, Vice President.

The New Wrtchard,

Washington, D. C., December 14, 191\%.

E. Clemens Horst Co.,

San Francisco, Cal.

DEAR SIRS: Have tried both samples of dried tomatoes, which I have obtained of Mr. Paul Boden, and have found them excellent.

Kindly advise where these goods can be obtained, also prices on same.

Would also like to have directions for preparing dried regetables, whether they should be soaked a length of time or not.

The above information will be appreciated by,

Yours, very truly,

C. E. Schaffer, Steward.

The Fairaront,

E. Clemens Horst Co., San Francisco, Cal.

GENTLEMEN : I have sampled your dried vegetables, tomatoes, puree, etc., and have found them to be one of the very best I have ever tried, and I shall be pleased to recommend them at every opportunity.

Very respectfully,

Martix Ginder, Chef.

\section{[Extract.]}

E. Clemens Horst Co.,

San Francisco, Cal.

Gentlemen: I am more than pleased with the samples sent to the hospital, and consider them a splendid article.

I wish to add that the drying does not seem to change the flavor in the least. It seems impossible to believe that they are not a fresh article after they are cooked.

Very truly, yours,

Mabel B. WebB, Hospital Dietitian. 
[Extract.]

California state Board of Health,

Bureau of Tubercutosis,

Mr. Clemens Horst, sacramento, November $16,191 \%$.

San Francisco, Cal.

Dear SIR: I wish to thank you for the samples that you sent us, and to tell you that I have never tasted better tomato soup than we made from the powder.

Yours, rery sincelely,

E. L. M. Tate-Thompson, Director.

[ Extract.]

E. Chemens Hokit Co..

San Fralleisco, Cul.

Gextuzmen: Refelling to sample of aried tomatoes recently submitted, beg to advise that our dietitian finds that same made a very excellent soup. It is our belief that this product would be particularly advantageous for use in the Army, and wonld solve, to a considerable extent, the problem of transportation of large quantities of fool.

Respectfully:

R. G. Brovkick, superintendent.

\section{[ Extract.]}

Say Fraycisco Hospital. San Francisco, December 1:, $191 \%$.

\section{Hotel St. Francis, San Francsico, December $1 /, 191 \%$.}

Mr. E. Clemens Horst's Julienne ant Brussel sprouts (dry) have the flavor and taste of fresh vegetabls: after being prepared same way as fresh, and recommend then very highly.

ViCTOR HIRT\%LEK.

\section{[Extract.]}

E. Cremens Horst Co.,

Hotel St. Francis, Sull Francisco, November 10, $191 \%$. San Francisco, Cal.

Gentuemen: For the first time in my experience as culinary chef and cook I have used one can of your dried powdered tomatoes and served it the whole day. I can only say one word-" excellent."

Yours, very truly,

VICTOR HIRTZLRR.

[Extract.]

PaLACe Hotel,

E. Clemens Horst Co., San Francisco, Cal., November $23,1917$.

San Francisco, Cal.

Gentlemen: I have given your tomato preparation, both the dried as well as the powdered forms, a good trial and am glad to state that your products are fine. They may be used with very good results in all such dishes where tomatoes are used.

Wishing you the very best success, I am,

Very truly,

E. Burgen ninter, Chef, Palace Hotel. 
[ Extract. ]

Mr. E. Clemens Horst, City.

San Francisco, December $15,191 \%$.

DEAR SIR: We are jleased to advise you that we sampled the dried Julienne vegetables and prepared very palatable vegetable soup from same.

Very respectfully,

Techav Tavern Co.,

A. C. Morkison, Manager.

Messis. E. Clemexs Horst Co., San Francisco, Cal.

DEAR SIRS: I have tried sour tomato dry powder in our kitchen and have found it very satisfactors. Have no doubt that it would be very useful and economical.

Very truly, yours,

Sax Francisco, November 21, 1917.

Mr. E. Clemexs Horst,

San Francisco.

Dear SIr: In reply to your communication of the 14th. will saly the Julienne soun mixture you sent us makes exceptionally good soup, so much so that we are interested in the other articles you have on the market, and have instructed our buying stewark, Mr. Barta, to get in touch with you.

Yours, very truly.

Tait-Zinkand Caft,

By G. Mrthan, Chef.

Clift Hotel,

San Francisco, December 15, $191 \%$.

H. S. WARD, Assistant Jfannger.

[Extract.]

San Fraxcisco, Decembre 18े, 1917.

Mr. E. Clemens Horst, Sill Francisco. Cal.

DEAR STr: Replying to yours of the 1tth instant, we beg to alvise that we have to-day cooked the Julienne you wished us to test and find it excellent in every respect.

Yours, very truly.

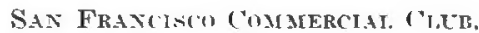
Prosper Reiter, Wimanger.

THE (ILTMPIC ( I.T'R.

E. Cuenens Horst ('o., San Firncisan, Cal.

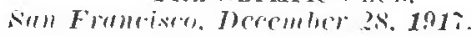

Gentmemen: We received your sample of Tulienne sum nixture the early part of the month and can particularly recommend sime. The veretables are also the finest we have ever tried, and, with proper halulling, they sem to retain the flavor and appearance of the fresh vegetahles.

Yours, truly.

J. H. Nisol. Nilnerintendent of siremere.

McKint.y ORPHANAGE.

E. Clemens Horst ('o.. San Fromeiseo, January tis. 191 s.

Sall Frantinato.

Dear Sir: We receivel the simmle uf rum driel soup regetuhles. We have userl the sample and find it excellent-just as good as fresh regetables. A little later on we will get in a suplly of your dried regetalules.

Yours, truly.

IJILIIIX R. COURNEF, Per E. NIELD. 
P. ("Lenens Honst Co., san lirancisco.

Sin Francrsco, January $9,1918$.

(iknthares: We received your letter, together with sample of your dried vegetables. We tried them at your suggestion, and we want to say that we - found them rely sitisfuctory; the flavor was full delicious, with no trouble to prepale. If they (am be supplied at the same price as fresh vegetables, or very near it, we should think they would be a wonderful acldition to Arny, Nary, and any camps; also, a great solution for the use of overproduction in the country. One rearlis of boatlonds of regetables dumper in the bay for no other reason than to keep up the prices. Why not dry them? They are not iffererl to charity, I notice, when the markets are glutted.

Thanking you for your favor' in bringing these regetables to our notice, and nishing you all success,

Fours, rely truly,

( Altiornta HoMe for Giris, ARXETTE BIACKBURNE,

-

Hiserutire secretary.

THE STRATTOI: HoteL,

Uhicagn, January 23, 1918.

W. CIEMENT Holst Co.

Ślull Franciseo, cal.

Gexthencx: After having given roil dry regetables a thorough trial, I am ylenserl to state to you that they are very sitisfactory, and as soon as you have them in quantities so that they will be put on the market, will you please send mo : 1 rice list. and I shall be glad to give you an order.

I tind that the flavor is much fresher after they have been prepared than that of cimmed goods, and it is much ensier to keep and to store.

Yours, respectfully,

G. A. RISSER, Chef.

Mr. Honst. The testimonials include practically all the highestclass hotels, hospitals, and clubs in San Francisco. The recommendations and use of dried regetables by the best San Francisco trade is of particular importance, in that California always has fresh vegetables.

So much for the question of quality.

As to the subject of expense, of course the dried regetable is not going to be as cheap as the fresh regetable, because there is the cost of drying; that is, if you take the fresh regetable in season and dry it you have the additional expense of drying the product. But. when rou take the regetable out of season, then the dried product will be cheaper than the fresh product and far cheaper than the canned goods. For example, a case of canned tomatoes that costs roughly $\$ 4$-solid-packed tomatoes-two dozen tins, which weigh 2 pounds each, the gross weight of the case being 60 pounds, and you have $\$+$ for a case of tomatoes containing a total of not over 15 cents original cost of tomatoes. In other words, you have spent $\$ 3.85$ to preserve 15 cents' worth of tomatoes.

The same illustration holds good in a number of other products to the same extent, and to a lesser extent in all vegetables that are canned. The cost of dried regetables is the cost of drying plus the cost of the fresh vegetables; in other words, in round figures, the cost of dried regetables is less than double the original farm price of fresh vegetables, while with canning it takes approximately twenty times and often more than twenty times the cost of the fresh vegetable to make the cost of the canned product.

The Chairman. That is 2 against 20.

Mr. Honst. Those are round figures. The figures vary according to different products. 
On the question of weight and transportation, a 60-pound case of canned tomatoes, when the tomatoes are dried, gives you in round figures $2 \frac{1}{4}$ pounds of the dried product.

The same illustration roughly holds good of other vegetables, like spinach, and perhaps sprouts, and all these other light-weight vegetables that contain much moisture say, something like 75 to 95 per cent moisture.

When you have canned goods, vou have to ship not only the canned goods but you have to ship an equal number of cars of finpty cans to the cannery. Ficr instance, 30 cacloads of canned tomatoes would be equal to 1 carload of dried tomatoes. And you take your 30 carloads of canned tomatoes

Senator simis of Georgia. In weight, but not in bulk?

Mr. Horst. In equivalent quantity; that is, if you take the tomatoes of 30 carloads of canned tomatoes and dry them you will have 1 carload of dried tomatoes.

Senator Sirtr of Georgia. In bulk--in spac. I mean-it would only occupy that much space?

Mr. Horst. They will occupy that much spac: yes, sir.

Senator Suris of Georgia. That is what I mean-take no more space.

Mr. Horst. The contents of 30 carloads of canned tomatoes

Senator Sirtir of Georgia (interposing). Can be put in 1 carload.

Mr. Horst. Can be put in 1 carload; yes, sir. When you have vour 30 carloads of canned tomatoes, you have to add on another 30 cars for the morement of the empty cans from the can factory to the camery. That makes 60 cars.

Then, again, when you have in a carload of canned tomatoes 10,000 pounds of tin and 14.000 pounds of lumber, a total of 24,000 pounds. Then you have the movement of the tin-making material from the mines to the tinplate factory, and the morement of the tinplate from the tinplate factory to the tin-can factory: and the morement of the logs to the sawmill and of the lumber to the box-shook factory, and the box shooks to the cannery, which gives you a grand total of about 105 carloads as against 1 carload of dried product.

Senator R.ixspeLd. Is that one carload of dried product just as valuable as the other for human consumption?

Mr. Horst. Yes, sir. And for that purpose I have brought plenty of samples that anybody and everybody may try them. These products have been tried now by the Walter Reed Hospital here for the last few weeks since I have been here, and they were tried at the Washington Barracks within the last few days. They have been tried all along the line and every one certifies to the excellence of the product. All are agreed that they are better than canned goods, and most of them agree that they are as good as the fresh vegetables in season and better than fresh vegetables out of season.

Senator Sunt of Gcorgia. They are as good as the fresh regetables, unless you get the fresh regetables right off the farm. If the fresh regetables hare to be delayed, as I understand you, in trunsportation and distribution in a city, from a farm some little distance away, then they are just as good as that kind of fresh vegetables.

Mr. Honst. That is exactly it. 
Senator NorRIs. What about the expense of the preparation of the plant, the drying machinery, etc.?

The Chairman. Senator Norris, would you mind, before you proceed, allowing me to continue for a moment. I want him to illustrate the shipping in order to get the sequence.

You were telling, Mr. Horst, about the expense of shipping tomatoes to Havre, France.

Mr. Horst. If you take this case of tomatoes, that would cost you, say, \$4 in New York, by the time you shipped that case to Havre, at the present freight rates and at the present war-risk rates, it will make your deliveries in Havre, roughly, $\$ 7$ per case, while if you take this product in the dried state you have got a correspondingly less freight rate according to the difference in bulk, which, as I say, is less than 5 per cent of the bulk. And by having a lower cost in the first place, you have a lower war-risk insurance, and the differences become greater the greater the distance that you move your product and the greater freight rates that you have to contend with.

Just before I left California I saw a shipment of 50 pounds of green sprouts from California to some point East, where the express rate is 12 cents per pound. In order to ship these 50 pounds of green sprouts to the Fast they had to ship a 100-pound cake of ice and pay the expressage at the rate of 12 cents per hundred pounds on the ice and the 50 pounds of sprouts, making 150 pounds at 12 cents a pound, which made $\$ 18$, to ship this 50 pounds of sprouts. The whole 50 pounds could have been dried and shipped as 3 pounds by parcel post at a cost of 35 or 36 cents instead of $\$ 18$ for expressage alone, and not counting the cost of the sprouts and ice. So that the differences in cost for vegetables, no matter how you figure them, is in favor of the dried product; and, of course, when you start in figuring the movement of fresh products by express the figures are staggering. When you take these sprouts and dry them in any place where they happen to have been grown, you dry them fresh the same day you pick them, and you have a product that is substantially equal to the fresh product, and a product that you know positively is never going to spoil, at least in a reasonable length of time.

Senator SмIтн of Georgia.. Then, in shipping fresh vegetables there is a substantial loss, despite the care used, in the vegetables that are not kept fresh.

Mr. Horst. It is estimated that of all of the vegetables grown in the United States, potatoes included, that there is about 40 or 50 per cent of the product that never reaches the dinner table; those are the losses between the farm and the consumer and by the consumer.

Under the drying process there is no loss whatever. The entire product; that is, the sound portion, the edible portion, of the entire product is saved.

The Chatrman. You told me yesterday that something was saved in the drying process that was lost even in the canning process.

Mr. HonsT. In the drying process you save the tops in the gardens and use them for feeding cattle, and the peelings of the product you save in the drying process and use them for hog feed; and you have them at those evaporating plants in sufficient quantity to raise hogs on the peelings and raise cattle on the tops. 
The Chamran. You did not quite get in another point-that is, that there is some kind of salts that are saved.

Mr. Horst. In all vegetables that are canned the valuable mineral salts are very largely leached out in the cans. That is the case in spinach, particularly. If you take spinach and put it in water and leave it in water two days you will turn the water absolutely black from the salts. In the canning process, or where the stuff remains in the cans on an average of six months from one season to the other, you have lost the very properties that you want to save, and although you may save in cooking you will put the entire contents into the pot when you are cooking it, still the salts have been lost to a rery large extent. While in the drying process it is entirely sared.

Senator RANSDELL. How do you pack these different vegetables for preservation and shipnient; for instance, tomatoes?

Mr. Horst. Te pack them in carton boxes of pasteboard, which are sufficient for all vegetables, with perhaps the desirability of wrapping tomatoes and onions in the carton, and then having thin paraffin paper on the outside or inside in order to keep off the moisture. The tomatoes and the onions will take on moisture after dried, although. they do not take on sufficient to hurt them. I have had onions and tomatoes exposed to the damp atmosphere of San Francisco for a period of two months' time without any injury whatever to the product, although they have taken on a great deal of moisture. They take on moisture just so far, and then they stop and they are not hurt.

The Chatrmax. I do not know whether this process of drying fruits and vegetables differs from the one used in Germany and whether it explains to some extent the wonderful power of endurance of the German people. I understand you know something about that.

Mr. Honst. The drying plants in Germany are estimated to be in number somewhere between 1,000 and 2,000 . There were something like 850 plants before the war, and it is reported-how reliably I do not know- that they now have close on to 2,000 plants. the purpose being, of course, to save everything.

The Chamman. And the potatoes-how extensivelr do they dry those?

Mr. Honst. The quantity of potatoes dried in Germany for the last year of which there is official record by our Government is $800.000,000$ bushels, which is more than twice the quantity of potatoes that are raisel in the United States per annum: and figuring it on a per capita basis it is seven times as many potatoes as we raise. On top of that quantity, of course, Germany raises a very large additional amount of potatoes. Their crop in 1915 , according to our Government Yearbook, was, in round figures, 2,000,000,000 bushels, as against $350,000,000$ bushels in our country.

The Chairman. Those are Irish potatoes?

Mr. Honst. Those are Irish potatoes.

The Chatrian. Does this process preserve siveet potatoes equally as well as Irish potatoes?

Mr. Honst. This process will preserve sweet potatoes and Irish potatoes, and all other products, equally well.

Senator RANSDELL. Are you going to tell us how to do that? 
Mr. Honst. Yes, sir; I am going to tell you everything I know about it.

The process of doing this is very simple. It involves no patents whatever-that is, the process itself involves no patent. There are minor features of it, perhaps, affecting the cost of operation that are covered by patents, but they can be utterly ignored, as they are of no value whatever in the general proposition. The business is very simple; there is no secret about it. The sum and substance of the proposition is to dry the product quickly, and not too quickly, and to use only air in doing it. And any plant by which the air is run through the product in sufficient quantities will dry the product in proportion to the water-carrying capacity of the air that is passed through the product. In other words, if you take air at ordinary humidity, say, about 75 per cent, there is the 25 per cent left for water-carrying ability of the air, and at low temperature that watercarrying capacity is very small, and you would have to drive enormous quantities of air through the product, while by raising the temperature to, say, $130^{\circ}, 140^{\circ}$, or $150^{\circ}$, you do absolutely no injury to the product and you greatly increase the drying capacity of the air. In other words, say, at $150^{\circ}$ you dry roughly about 10 times as fast as with air at $80^{\circ}$. I have not those figures in my mind, but I have a memorandum here in my pocket from which $I$ can get the figures, if you care to have them.

Senator RANSDELI. 'Then there is a drying machine of some kind that has to be used?

Mr. Horst. You may call it a machine. It is simply a plant on which you lay your product on a tray and blow air through it.

Senator Ransderl. Practically, if I wanted to use it on my farm, what would I have to do?

Mr. Horst. You would have to get a blower and a steam coil and a boiler, and heat the steam coil, and pipes to lead the air from the blower into the room in which the products are contained.

Senator RANSDeLL. You have a closed room to put them in.

Mr. Honst. You would have a closed room to put them in, and by doing it on that plan, and by doing it quickly you avoid the oxidization of the product; you retain the original freshness in color or substantially so, and you do your drying without the use of any sulphur or preservative. These samples that are on the table here are all the natural products without anything on them, and a product that anybody can turn out equally well after he has had a very short course of training.

Senator RAN SDELL. What would be the cost of the simplest mechanism or outfit that you could get up?

Mr. Horst. You can get up a home dryer with which you can dry celery tips and your odds and ends around the house. The Department of Agriculture has been working on it; they have the plans, and they know the cost better than I do. But it can not be more than $\$ 20$, I suppose. Of course you have not much capacity with such an outfit. For practical business--that is, to run drying on a scale such as it ought to be done in this country-you will need large plants, and those plants ought to be distributed throughout the United States in the agricultural districts to arrange for the different products. 
Senator Smirh, of Georgila. Does it require a separate plant for each product?

Mr. Horst. Oh, no; one plant does everything; the same plant that dries tomatoes also dries potatoes.

Senator Ransdell. You mean community plants?

Mr. Horst. You can call them community plants, so long as you have the plant, community, individual or corporation.

The Chairman. What would be the cost of an economical plant for uses such as you have described?

Mr. Horst. You can put up a substantial plant all the way from $\$ 5,000$ to $\$ 50,000$. Of course everything depends upon the kind of a structure you are going to build to dry in, and if you make your drying building brick you are going to have a much lower cost of operation than if you make it of frame, because your brick building will save your heat that you would otherwise lose in the frame building; and the other things depend upon the price you are paying for your fans and the steam coils.

Senator Norms. The steam coils are to heat the air?

Mr. Horst. 'They are to heat the air.

The Chalrmax. And then you must have steam power to operate the fans?

Mr. Horst. We must have power to operate the fans. An automobile will do, or a little motor will do it. In our plant we use a boiler for making steam. We run the steam through the steam coil, and then we use electric power for operating the fan.

Snator Yoriss. It would not take much power to operate the fan?

$\mathrm{Mi}$. Horst. It would not.

Senator NonRIs. Then you have to have a place where the air goes in?

Mr. Horst. Yes, sir.

Senator Yorris. A place for it to come out, and passing through the building it goes over the fruit.

Mr. Honst. Yes, sir.

Senator Norris. That is the whole thing?

Mr. Honst. That is the whole idea.

Senator Ransoelu. You have got to heat that air somewhere?

Mr. Honst. You heat the air by passing it over the steam coil, and the whole principle is to heat the air so you do not heat it and lose it.

Senator Norris. But the heating is outside of the building that has got the fruit in it, I suppose, is it not?

Mr. Honst. The heating plant may be either inside or outside the building.

Senator Norris. And the fan is put right at the entrance, I presume?

Mr. Horst. Of course, you can supplement that, if you like, by putting further heating coils inside of the building if you want to do that. In other words, the higher the temperature you work at the quicker you dry. For every $24^{\circ}$ increase in temperature you double the drying capacity of the air.

Senator Norkis. Tell us how long, in a properly equipped plant, it would take to dry potatoes.

Mr. Honst. You can dry sliced potatoes all the way from about two hours to eight hours, according to how thick you lay them and 
and according to the temperature of the air that you are using. Tomatoes we dry in about 7 to 10 hours.

Senator Ransdell. You slice them, I suppose.

Mr. Horst. Yes, sir.

Senator RansDell. All vegetables have to be sliced up, or pructically all of them?

Mr. Hons'r. Iou have to slice your products in order to dry the vegetables on the inside and core. If you leave a wet place in the inside of the vegetable, then your vegetable is liable to spoil, and that has been the mistake of the past, -before that was fully understood, that the inside of the vegetables - that is, the core -has to be dried, and when the core is not dried your vegetable will spoil, and when the core is dried you can not spoil it afterwards.

The Chairman. You were telling me about some saving in the drying of apples under this process, as compared with the old process.

Mr. Honst. There is a great saving in the drying of apples, in this particular respect, that you get much more for the apples that are dried by the incloor process than you do for apples which are dried by the outdoor process, and in that way you get your saving.

The Champax. Was there not some bleaching process that you told me about?

Mr. Horst. Whenever you dry anything in the open air, like peaches, pears, or apples, and lay the stuff on trays, the clrying precess is so slow, no matter how hot the sun may be, that the outside of the fruit becomes oxidized, and during the exposure there are flies and bugs and dust and dirt which get on it and damage the product more or less.

In order to make the product presentable, it is imperative to bleach it, or yon can not dispose of it, the way people look at goods nowadays. The sulphur bleaching proposition will all be clone array with by this dehydrating process, becanse there is no need of sulphul. since you get your first-class product without its 17se. The danger of sulphur is not so nuch in the sulphurous acid that is formed in the process of the burning of the sulphur, the sulphur smoke. Sulphur smoke coming in contact with the food makes sulphurous acid, and then that is the bleaching agent. Bad as that is the real trouble is that it is very difficult to get sulphur that is free from arsenic, and when you burn sulphur under fruit the arsenic burns along with the sulphur, and that is immediately precipitated when it hits anything wet.

The first product it hits when the smoke is cooled, wherever that happens to be, the arsenic is precipitated, and when this arsenic is precipitated on the lower layers of the fruit, and if perchance somebody eats the lower layers and gets a little too much arsenic, there is a funeral in the family. The amount of arsenic, for instance, in Hakodate sulphur and Sicilian sulphur runs as high as 1 part of arsenic to 1,500 parts of sulphur.

Senator RansDell. How it is with respect to the Louisiana sulphür?

Mr. Honst. Louisiana sulphur is considered pure; that is, free from arsenic. So is the Nevada sulphur, but we never get any of the Nevada sulphur, nor do we ever get any of the Louisiana sulphur out in our part of the country, and the only sulphurs used are the 
Japanese sulphurs. There is one sulphur in Japan, the Bongo, that is comparatively free from arsenic. But it all has arsenic in it, even after it has been refined, and to my mind too much of it.

The Chrimman. Can you tell us what has been the experience of the English Government with reference to the number of drying operations they have in use!

Mr. Horst. The official records that come through our Food Administration-any they give the information as coming through our Wal Department-is to the effect that England uses for its armies 100 pounds of dried regetables for 6,000 portions of regetable soup, and that they feed the vegetable soup to the soldiers five or six days a week, and with that ration they keep them in first-class health. The British Government has bought in Canada since the war commenced, in round figures, 44,000,000 pounds of mixed dried vegetables and potatoes. On top of that they have secured large supplies in England, where they have converted many of the hop kilns into regetable clrying plants, and $I$ believe they have put up other vegetable drying plants.

Senator Norris. Take an apple. I suppose we are all more or less tamiliar with dried apples. Will your process dry an apple so that it would be as good as a fresh apple?

Mr. Honst. It will dry it so that it will be as good as a fresh apple cooked. I do not say that any product that is dried and soaked in water again is going to be as good as fresh, if eaten uncooked.

Senator Norris. How will it compare with the dried apple we are all familiar with, that we used to dry in the sun?

Mr. Honst. It will be far better than a dried apple that has been dried in the sun, because the apple drying in the sun takes too long a time to dry and becomes damaged in the too slow drying.

Senator RansDelc. WVill the apple dried by this process make practically as good apple pies as the fresh apple?

Mr. Horst. Substantially as good; yes. The apples dried by this process bring in the wholesale market 3 cents a pound more than apples dried in the sun, and when I left San Francisco one of the largest stores in that city, the Emporium, a department store, was selling Oregon dried apples, dried by this same process or similar to this process, and getting 45 cents a pound for them in 1-pound cartons as against the wholesale price of about 16 cents for the ordinary dried apple.

Senator Norris. One pound of those dried apples would be equivalent to about how many pounds of fresh apples?

Mr. Honst. I have not the conversion figures in my mind now on apples. I have been working almost entirely upon regetables, and I can give you almost all the conversions on vegetables offhand.

Senator RansDell. Are there any grocery stores in Washington handling these dried products?

Mr. Horst. No, sir; not yet. The handling of the products is the lifficult part of the situation, and it is for that reason I was asked to come on to Washington to try to interest the Government in two things: First, for our Army to adopt dried vegetables, and, second, for our food authorities to make a propaganda so that the people will know what the products are; that is, to make whaterer public tests are necessary to demonstrate the value of the product, and then have 
the information go officially before the public, so that the public will ask for it and so the farmers will raise the raw material necessary, and on that basis it will mean millions upon millions of tons increased food production by way of vegetables.

The Chamman. By this process there are no perishable products lost?

Mr. Horst. No, sir. The highly perishable products are converted jnto nonperishable products.

Senator RansdecL. No expensive glass vessels are required to hold them?

Mr. Horst. No glass, no cans; pasteboard is all that is needed.

Senator Raxspecc. And pasteboard is made of waste products from the top of trees that would otherwise be thrown a ray?

Mr. Horst. I do not know-

Senator RANSDELI (interposing). It can be made of that material.

Mr. Honst. I understand it is made of cheap wood pulp.

Senator Grox vil. Do the regetables preserved hy this process lose their flavor?

Mr. Horst. Vegetables will not lose their flavor as compared with cooked vegetables. If you take a raw vegetable, dry it, and then soak it-that is, put the water back in it-it is not going to taste, uncooked, the same as the fresh fruit or vegetable does before dried. But if you take the two products and cook them, then you have the dried product at least as good as the fresh product, unless, per chance, you take your fresh product directly on the farm and eat it on the farm. You get a crispiness and snappiness on the farm that you do not get in the city.

Senator GronNa. In this tremendous reduction of potatoes, for instance, which contain a high percentage of alcohol, are any of those ingredients lost?

Mr. Honst. There is absolutely nothing lost.

Senator Smith of Georgia. All the alcohol, all the liquid, in the potato is lost by evaporation.

Mr. Horst. You have got Dr. Alsberg here and I would be afraid to say anything about chemical action in his presence, but it is $m y^{r}$ impression that alcohol is not formed in the potato at the time roit are using the potato, and in the drying process the only thing that is taken out is the water, and the United States Department of Agriculture, Bulletin No. 841, I believe it is, states that in drying vegetables water is all that is taken out, and that flaror, texture, and food value are unimpaired.

Senator Smrty of Georgia. The water is withdrawn then before the process of producing alcohol from the potato takes place?

Mr. Herst. Yes, sir.

Senator NorRIs. That is true of every vegetable, is it not?

Mr. Horst. Yes, sir.

Senator Norris. You could get the alcohol out of them, but if you dry the potatoes when fresh you would dry them before they hippened to be any alcohol in them?

Mr. Horst. Yes, sir.

Senator Gronna. My question, of course, was really this: Has the ingredient, as I call it, which makes the alcohol, become lost in drying the potato?

42291-18-? 
Mr. Honst. No, sir. You lost absolutely nothing but water, and you can put the water back, but in putting it back, as I say, if you are going to compare a vegetable with the water put back with the same vegetable before it was dried, and eat the thing raw, you are bound to be disappointed; but if you eat one cooked and the other cooked you will like one just as well as the other, unless you get the one fresh at the farm.

Senator RANSDELL. I am interested to know whether or not you could still use these dried vegetables to make alcohol, if you desired?

Mr. Horst. I believe they use it in Germany to a large extent that way, but I do not know.

Senator RANSDELL. I imagine so, from what you said.

Senator Grox sa. I am intensely interested in that, and $I$ think the material out of which the alcohol is made is the food product. I think that is conceded, is it not?

Mr. Horst. That is a question, I am sorry to say, which is over my head.

Senator Grovis. What I was about to say is this: If it should appear that this very material out of which you could make alcohol disappears I think that would be a tremendous loss in food value.

The Chamman. Mr. Horst, I wish you would file with your statement these conversion figures, or ratios, the weight of the fresh vegetable as compared with the dried vegetable.

Mr. Horst. I can give them to you in round figures. For instance, potatoes, about 6 to 1 ; cabbage, about 20 to 1 ; tomatoes, about 20 to 1 ; spinach, about 18 to 1 ; turnips, 14 to 1 ; carrots, about 9 to 1 . That gives you the general relation.

Senator NorRis. That is bulk?

Mr. Honst. In weight; and in cubic measurements you can take your dried products and compress them so that the question of bulk is entirely eliminated. We press cabbage, onions, spinach, and tomatoes. I have a little brick of tomatoes here, which weighs seren ounces, and five of those little bricks is equal to a 60-pound case of canned tomatoes; and I have the chemist's report on that quantitative analysis to confirm those figures.

Senator SMITH of Georgia. Will you state what your interest in the matter is, what your connection with the proposition is, barring the interest we all have?

Mr. Honst. I will tell you my interest frankly. 'I have been in the hop-growing business on the Pacific coast for the last 25 years and upward, and I have raised as many as 28,000 bales of hops a year, which is roughly several hundred times as many as the arerage hop grower raises, and the hop business has declined. The British Government has put an embargo on the shipment of hops, and 35 per cent of the hops used to go to England. and the American brewing business has declined, and as a result there are more hops on hand than people want, and $I$ have a large number of hop kilns and farming lands around these hop kilns. There are in the hands of other farmers on the Pacific coast approximately 2,500 hop kilns, constructed on a different plan from mine, but they can be adapted to my plans. All of these hop fields are in the very richest agricultural districts, and if I could find another industry for the hop grower it would be very good for the entire Pacific coast and it would be good 
for the country, because the same principle that could be worked from the Pacific coast can be worked in the East, South, and everywhere else in the United States.

Now, my desire is to make use of my hop kilns and make use of my lands, and grow vegetables; and unless the Government takes an interest in the proposition there is no chance of this industry developing, because of the fact that it is not a patented process and it is not a secret process.

Senator Smitr of Georgia. You have no financial interest in any process for this purpose?

Mr. Horst. Absolutely none.

Senator Smith of Georgia. It is just your suggestion that the Gorernment buy it in the interest of the public generally, without compensation to anybody, as an incident to trying it?

Mr. Horst. That is exactly it. In fact, I am making the fight against a number of people who have started in now to take this genernl proposition of dehydration and try to mike personal property of it and make patented claims on it in order to float stock and in order to queer the whole business before the country, but in any publicity given to this proposition it ought to be made perfectly plain that it is a proposition open to all and that anybody can do it. The benefit I am personally going to get out of it is that I am going to have better use of my lands than by raising hops.

Senator Smitu of Georgia. In other words, you would make a market for the product you have not got now.

Mr. Horst. Yes, sir. If we tried to create a market for these products by advertising it would cost at least $\$ 5,000,000$ to develop a dried fruit and vegetable product market to any substantial extent within two or three years, while if our Government takes hold of it and advertises it along the line that the product is good-and they can find out overnight that it is good-and if then the Government makes a very simple proclamation you will have every housewife wanting the product, and when every housewife wants products you can start in.

Senator RANSDELl. The consumer is going to derive a wonderful benefit from the cheapness of it?

$\mathrm{Mr}$. Horst. The consumer gets the benefit from the cheapness; the farmer gets the benefit from the better utilization of his lands. For instance, to-day the growing of regetables is confined, generally speaking, to within 2 miles of a city. When you get 3 miles away from a city you do not see any vegetable farms. I was on i little motoring trip of some to or three hundred miles in southern California last December, and when we would get 3 miles from a town you would see the most beautiful orange groves and the ground just as clean as a whistle and not a thing being grown between the trees, if grown even between the young trees, and that land lies absolutely idle and will not be of any benefit for many years, although every inch of that land could be put into vegetables and be a benefit to the whole country if there was an outlet for the product. But under present conditions if they grow vegetables on the land and have to rely on selling the product fresh or selling it to the canneries, there is a slump in the market and the stuff rots and the farmer is discouraged. Under this plan driers can be started by the farmers 
themselves or by associations of farmers in different parts of the country; all that land can be put into crops to the benefit of the whole country.

Senator RANSDELL. If your theory is correct and those products could be put in use, there would be a wonderful reduction in the cost of living?

Mr. Horst. Not only a reduction in the cost of living, but an improvement in the health of the people by eating more vegetables. As Dr. Wiley told me a few days ago, the people of this country do not eat enough regetable food to keep them in best health, and especially in the wintertime when the vegetables are high or practically none arailable.

Senator R.NSDELL. I took a sample of the dried tomatoes from the committee room and had my wife make tomato soup from the powder and it was rery good, we thought, but the idea struck me that while that would work with a vegetable that your were going to make soup of, for example, take cauliflower or cabbage, where you do not desire to use it in soup, but to eat the vegetable itself, how would you bring the regetable back so that you will be eating cabbage?

Mr. Honst. "The proof of the pudding is in the eating." We have served cabbage to 500-or something like 500-men at the Nalter Reed Hospital, and I do not know whether they serve it full portions, but they serve something like 4 or 5 pounds of dried cabbage for the whole 500 men, and the cabbage was pronounced excellent by all the men.

Senator Norris. When that cauliflower in the glass here [indicating the glass on committee table] has been soaked up, it will never come back again to as large a head as it was originally?

Mr. Honst. Those are only little parts of the head; that is not the whole head.

Senator Torris. Take a cabbage head. Would you dry the whole head or have to cut it up?

Mr. Horst. You could not dry the whole head.

Senator Norris. You would cut it up?

Mr. Horst. We would cut it up.

Senator Norris. And malie it into a kind of cabbage slam?

Mr. Horst. You can slice or split up the cabbage head. You have got to make the bulk small enough so that, you can dry the inside part. Wherever you reach the point where the drying stops so that you can not dry the inside, you must stop. You must make rour product small enough so that the inside can be dried. But that gives you plenty of latitude to take care of ererything.

The Chairman. Will you put in your statement along with the letters from the Ritz Carlton and Willard Hotel the letter from the Walter Reed Hospital, when you get that later?

Mr. Horst. It is not available at the Walter Reed, but the oral report from the Walter Reed Hospital and the Wishington Barracks was that the products are excellent.

The Chamrinan. Te are very much obliged to you, Mr. Horst.

Senator RANSDELL. This is the most profoundly interesting thing we have had before this committee for our consideration since I have been a member of it. If the results are as Mr. Horst says, it is perfectly remarkable. 
The Cramman. If this process is equal to its promise, perishable products will be made nonperishable, and the summer will be made perpetual and we will eliminate an enormous amount of waste.

The Chamman. We will now hear Mr. Sweet.

\section{STATEMENT OF MR. LOU D. SWEET, UNITED STATES FOOD ADMIN- ISTRATION, WASHINGTON, D. C.}

The Chammax. Please state your name, Mr. Sweet?

Mr. Sweet. Lou D. Sweet.

The Chatruran. And your present address.

Mr. SwEET. Food Administration Building, Washington, D. C.

The Chairman. We will be glad to hear any statement on your part concerning this process of dehydration of fruits and vegetables, in your own way. You are at liberty to speak as appeals to you.

Mr. Swewr. I was asked by Mr. Hoover in July to take up the subject of dehydrated regetables and fruits. I began to collate the information I conld get a hold of, first, from the United States Agricultural Department, through the kindness of Dr. Alsberg, Dr. Gore, and Prof. Corbett, and others, from whom I learned much, as Mr. Horst has told you, about the English Government, particularly, ordering the soup product for the Army in South Africa during the Boer war. That was made of about 40 per cent potatoes, 20 per cent carrots, 20 pèr cent turnips, 10 per cent cabbage, and 10 per cent onions, drying 100 pounds of the raw to about 15 pounds of the dried. That was shipped to them in large quantities. Their statement was that 100 pounds of the dried would make a soup ration for about 6,000 soldiers, and five or six rations a week would keep them in health. The Boer war closed suddenly and left him with about 30,000 pounds of the products on hand. There was no demand for it in Canada or the United States. He put it into barrels sealed it up with paraffin and fifteen years, three months, and some days after that, or after this present war had started, England sent him another order. He opened those barrels and it looked all right, and he shipped it and it proved all right.

Since that time the Graham Products Co. (Ltd.), at Belleville, Ontario; the Chilliwack Operating Co., at Chilliwack, British Columbia, and the Dominion Products Co., of Vancouver, British Columbia, have shipped up until about the 1st of December between $40,000,000$ and $50,000,000$ pounds of dried products, about 60 per cent of it in the form of this soup product they call "Julienne" and about 40 per cent of the dried sliced potatoes. They require that this product be put up in 15-pound tins, two tins to a case, and a good strong case made for it, as they use it in all parts of the world where they have their armies.

They placed an order in November with the Dominion Products Co. (Litd.) for 4,000 tons, about 60 per cent of the soup product and about 40 per cent of the dried sliced potatoes. In the United States we found that the American Dehydrating Co., at Waukesha, Wis., was one of the earlier companies making a product for the IIudson Bay people, away up north, where their men needed vegetables to keep them healthy; next came the Wittenberg-King Co., of Portland, Oreg. The Alaska boom started them making it up there. They 
make a very good product, shipping their products mostly to Alaska. During the last six months there has been a wonderful awakening in this country on dehydration. The Bureau of Chemistry, under Dr. Alsberg and Dr. Gore, has made exhaustive study and tests of it. There have been a number of patents granted to various people. Some have been promoted, selling people their patent processes. Little plants have started here and there, some of them making a fairly good product and some not so very good. But during the past five or six months there have been a number-some two or threethat have made a product comparable to the fresh product. I mean by that that as we take the fresh vegetables from the garden and prepare them for our meal we have a delicious product, while if it is shipped from the place where raised into the city, an average of two or three days transpires probably before people use it, and those vegetables are not what we would consider tresh and delicious vegetables. The dehydrated products, or the good products to-day, after they have been dried and all the water laken out of them, can be placed back in cold water and take on the moisture that they originally contained, or nearly that, and then be cooked, and we are unable to tell the difference between those and the fresh vegetables.

The Chatrman. Would it not be possible, Mr. Sweet, in those markets of the city where there is a great deal of waste in perishable products to install these plants and save all of that?

Mr. Sweet. Would it not be better for the plants to be elected where the products were grown and sent : $;$ the cities in the manutactured form?

The Chamman. Oh, undoubtedly; that is the idea I have, and that is what I contemplated in the bill $I$ have introduced but there is a great deal of waste in the big city markets in all our vegetables, and it occurred to me that you might install those plants at the markets and work up what could not be sold.

Mr. SweEt. The main point in fresh vegetables, as $\mathbf{I}$ see it, is that during the nonproductive season or winter season, with a dehydrated vegetable, the people of the United States could get a product equal to fresh vegetables, and they would be healthier, and I firmly beliere that the dehydration of fruits and vegetables is one of the grandest developments that has come to the United States.

Senator Ransdexl. Have you made estimates as to the comparative cost of these dehydrated vegetables, with the ordinary canned vegetables, or vegetables in the form we usually get?

Mr. SwEeT. Oh, yes.

Senator RansDell. How would they compare?

Mr. Sweet. Just a moment-

Senator RANSDELL (interposing). I am speaking now of the ultimate consumer.

Mr. Sweer. Potatoes will dry down to about one-fifth to one-sixth, according to the quality of potato. The food in the potato is, of course, the starch, the protein, and the mineral salts. In the rery high-class potato you will have a very high percentnge of those ingredients, and the poorer quality, of course, correspondingly less, and in the United States we have planted the cull potatoes, the little ones so long, have overcropped our lands so long, that our production per capita is the lowest of any country in the world raising 
potatoes, and the consumption per capita the lowest, because of the poor quality of our potatoes.

Of our 442,500,000 bushels of potatoes, that the Government states we raised last year, they also figure that only about 32 per cent of that ever moves out of the country in which raised. They also figure in Bulletin 47 that the consumption per capita of potatoes in the United States is about 2.6 bushels per capita. Potato flour was made in Germany and shipped to this country prior to the war. We are now beginning to make some potato flour in the United States. Potato starch has been made in the United States more or less from the cull potatoes, that being used by the manufacturers for sizing of textiles, not an edible starch. The reduction of dehydration of the weight of the various vegetables varies with their water content, potatoes probably being from 100 pounds down to 20 or as low as 16 or 17 pounds, while some of the other vegetables will dry down to 8 pounds per hundred, according to their water content. You would lose the peeling in the dehydration, but far less peeling by machinery than you would by hand. The food of the potato, a large percentage of it, lies in that portion next to the skin, and the potato that is smoothe, with the eyes flush, by careful paring, would lose 5 to 15 per cent of the food; if it is 2 deep-eyed, rough, irregular shaped potato, would lose 30 to 60 per cent of the food, in the ordinary kitchen paring, while in the paring by machinery it is done with a centrifugal parer, lined with carborundum, which just wears the skin off. Dr. Gore, from the Government, can tell you more about the mechanical end of it.

The product sold in Canada to the English Government, the potato price, put up in these packages at the seaboard, has run from 20 cents to $32 \frac{1}{2}$ cents during the last three years; that is, in a large manufacturing way. In the United States, from the estimates we have of the engineers who worked with us, we believe we are safe in making the statement of 15 cents a pound, may be less than that, as compared to their 20 to $32 \frac{1}{2}$ cents.

With the other vegetables, the cost of preparing them for the de hydration is about the same as in canning; the labor expense necessary to wash them, and peel them, and prepare them, and slice them ready for the drier. The drying is a simple process of temperature and humidity to gradually get the water content out, and, of course, the packing is mechanical, in the lumber, the tin, or the carton, as it would prove better to do.

Senator RANSDELL. Summarizing all you have said, what would you make the average cost of the potatoes dried, as compared with the fresh potato?

Mr. SwEET. If you took 100 pounds of potatoes at $\$ 1.50$ a hundred and got 20 pounds dehydrated, the original cost would be $\$ 1.50$ plus the labor of preparing it and drying it and boxing it, the details of which I do not know definitely. We have had it estimated by a number of engineers.

Senator RANSDELL. But that does not answer the question at all. These potatoes would not be worth anything. like $\$ 1.50$ out on the farm where dried in the wholesale way. I was speaking about the fellow in the city who used those potatoes and paid $\$ 1.50$, whereas by this dehydrating process those potatoes are put up on the farm where they are worth practically nothing, wasted by rot, fed to hogs, 
or something of that sort, and I take it, if I understood Mr. Horst right, there would be an enormous saving to the ultimate consumer.

Mr. SweEt. There is no question about it at all.

The Chairman. There is an even greater saving in tomatoes and things of that sort, than potatoes?

Mr. Swers. There will be a great saving in potatoes, because of the reduced waste from the tremendous loss we are having to-day in handling potatoes by deterioration.

Senator' Smitri of Georgia. I understood you to say it cost 15 cents a pound average.

Mr. SwEET. That is the figure, about, for the dried product; that is what the dried product would cost.

Senator Smiri of Georgia. To change it from the green to the dried state?

Mr. SweE'T. I'es.

Senator Sirtir of Georgia. And then the additional cost would depend upon what was paid for the raw material?

Mr. SwEeT. Yes, sir.

Senator Surt of Georgia. What is the relative food ralue of the dried pound of the material before it was dried?

Mr. Swrer. I think Dr. Alsburg, Chief of our Bureau of Chemistry, can better answer that than I can. From all I am able to find out about it. hy eating them, as I have for some time, I can tell no difference between the good iehydrated products and the fresh prodnets. Dr. Mc('ullen, of Johns Hopkins University, says that he finds them comparable to fresh regetables, and he sees no reason why any of the food ralues should be lost. His experiments with a number of the regetables-cabbage and others-prove that they are as good as the fresh vegetables.

Senator SMren of Georgia. His theory is that the pound of dried potatoes has as nulch food vilue as the potatoes from which the pound of dried potatres were produced?

Mr. Sweet. True: yes, sir.

The Comirsax. And that anables rom to distribute the whole perishable crop orer the entire Lnited States!

Mr. SweEr, Now, it comes to the point of om Mrmy, they realizing now that they will neesl regetables abroad and can not obtain fresh regetables for' the summer' months.

Senator Surn of (reorgia. That in not a matter of expert testimony. We know as much about that as anybody.

Mr. SWEET. You know as much about that as anyborly, but the only point I was making was about the shipping (alpacity.

Senator Surri of Georgia. We understand the shipping matter. too. What we do not know is. what it cost to prounce this result and what the food ralue of the result is.

The CImImus. I think he told that in your absence, about the Fnglish Government.

Senator Smirm of Ceorgia. I heard that. If these potatoes have half the food value that the green potatoes have and at any reasonable cost they can bo dried, it is a perfectly clrar proposition that the (rovermment can not afford to wait to start drying.

Senator Nimris. I notice in these samples that the potalo samples were cooked before they were dried. Is that the usual way of doing it? 
Mr. SweEr. A good many of the processes wo know about blanch by steam, as they call it, to keep them from oxidizing and turning dark. After they are pared and sliced, they run them into a steam jacket, with steam pressure, and blanch them, and then go ahead with the drying process. Yon can, and they do turn out a prolluct of potatoes, where they cook the potatoes, then rice them, and then dry the riced potatoes.

Senat or Nonris. There is a sample of that kind right here.

Mr. Sweet. Ion can put that in hot water and in a very few minutes have as fine mashed potatoes as you can from fresh potatoes. With the dehydrated potato, as you would call it, you would have to put them back into the water and soak them up to their original shape and size and then go ahead and cook them.

Senator Noris. What I wanted to get at was, is there any practical advantage in cooking them before you dry them; is that more practical than to dry them without cooking them? I am moved to ask that question from the fact that I see on the samples of some of the vegetables that they were cooked before they were dried.

Mr. SweET. I take it, from a business standpoint, that the English Government, using them so long and using what we call the dehydrated potato, that they have proven to their satisfaction that that is the best for their needs.

The Cinumans. This experience, then, of using the left-over products from the Boes War would indicate that it was almost indefinite?

Mr. Sweet. I think so, Senator. I see no reason why it should not keep rather indefinitely.

The Ciramman. Thirty-six year's as well as 18 years, and so on. Is there any other question that any Senator desires to ask $\mathrm{Mr}$. Sweet? If not, we will hear Dr. Fairchild. I want to say, however, that we are very much obliged to Mr. Sweet for his statement.

\section{STATEMENT OF MR. DAVID FAIRCHILD, DEPARTMENT OF AGRICULTURE.}

The Chairmax. Doctor, kindly state your name.

Mr. FaIrChind. David Fairchild.

The Chairmax. What is your present address?

Mr. FarrchiLd. Department of Agriculture.

The Chamarax. What is your official position in the department, Doctor?

Mr. Finachild. I have charge of the introduction of nem food plants.

The Chummax. The committee will be glad to hear you in your own way discuss the subject of dehyclrated fruits and regetables.

Mr. Farrchrud. Last April I was requested by Assistant Secretary Vrooman to study this question from the angle which my own experience in the intruluction of new vegetables would enable me to give to it. namely, the problem of whether these dried regetables would be acceptable to the people. The experience which we have had in the introduction of such of these southern regetables as the dasheen, has given me a chance, perhaps, to throw a little light, from a Government standpoint, on this general problem of the human palate ind its effect on our agriculture. I.bring that matter up here 
because it is involved in this question of dried vegetables. The difficulty has always been in the introduction of a new food plant, that the growers of the plant could not advertise it; that is, it did not pay them to advertise it. The advertising which had been done by farmers, which has paid largely, as I understand it, is after an industry through various vicissitudes and many years has become established, and the farmers can form a large organization and control in some measure the output.

When it comes to a new plant like the dasheen, the Government has had to do the advertising, and we have now, after these years of experimenting, a crop of 30,000 bushels, which is nothing, of course. compared to what it could be, but it has been entirely done without any advertising on the part of the growers of this vegetable. That factor, it seems to me, enters into this whole question of what the Government should do with regard to dried vegetables, for, with all due respect to the testimony with regard to these things, they hare the character to the popular mind of something that is novel, something that is new, and they are going to meet with that same difficulty, perhaps in a minor degree, that every new food has met. The study which I have made during these months has convinced me, however, that the reflection which we get from Europe with regard to the resistance of the people to the changing of their food habits does not apply wholly to this country. I have traveled in all of these countries that are now at war. I have considered for years whether it would be worth while to try to introduce new vegetables into those countries, and I have long ago made up my mind that no money inducement would persuade me to try the experiment in those countries, because of the conservatism of taste. So when the matter first came up and I discussed it very extensively with men who had been on the Belgian Commission, particularly with relation to the difficulties in introducing Indian corn and rice, I realized that we were in a different position from that which they were in on the other side. We have introduced new foods. We have introduced more new fords into our menu in the last 25 years, I believe, than they have in Europe in the last two centuries, and I think that these foods have been introduced largely without much advertising-under the normal conditions of the public mind, skeptical. as it always is, toward the introduction of a new food. When you think of the successful introduction of such a fruit as the grapefruit, so sour that it made the lemon look like 30 cents-as the old grapefruit certainly did-when you realize that that fruit has not yet found its way into the European markets, you get some idea of what we Americans can do in this changing of our food habits.

The introduction of these dehydrated vegetables, as I said before, appears to offer less difficulty because of their cheapness.

The Criminin. Another thing, Doctor, it is a different form to what they have been userl to. It is not like a new and untried regetable.

Mr. Fatrchild. Exactly; it does not even have to have a new name, which apparently makes a great difference.

The work which I have done, consequently, has been largely along the line of testing these on the public taste.

Senator Smiti of Georgia. Doctor, before you go to that will vou tell us what you consider the relative food ralue? 
Mr. FAIRcIInd. I talked with Dr. McCollum, of the institute of hygiene of the Rockefeller Institute, yesterday afternoon over the telephone. $\mathrm{He}$ is now carrying on extensive experiments with 1,500 rats, testing all of these different vegetables. I said, "Doctor, what do you think with regard to this whole matter?" He said, "Mr. Fairchild, there has been altogether too much said with regard to the change in food ralues as the result of dehydration. In my opinion, gathered from my own experiments and the evidence gathered in Germany, the food values remain the same."

The Chatrman. That is the testimony of the rat, is it? [Laughter.]

Mr. FaIRCHILD. It is the testimony of the rat, and rats are extremely sensitive, and live on the very kinds of food that human beings do; and they are, as I understand, recognized as standard test animals in these matters of food digestability and nutrition value.

Another point which I wish to put into the record relates to these substances which Dr. Alsberg knows a great deal more about than I do, of course. Dr. McCollum's attitude, as I understand it, toward these so-called vitamines is that the leaf regetables, such as cabbage, spinach, and cauliflower, contains more of the substance which he calls, for lack of a better name, his "water soluble B" than do the fruits and the root vegetables. Now, he feels that, owing to the high price of certain vegetables in the wintertime-for example, cabbage is selling now for $\$ 4$ a hundred pounds in our local market here-the consumer, with a limited pocketbook, is going to buy his grain products and his essentials as he considers them and cut out these green-leaf vegetables. According to Dr. McCollum's investigations, that is a great mistake; that the children particularly, and even the grown-ups, need this particular substance which occurs in largest amount in these green vegetables, and which will not be bought by the consumers during the high-priced vegetable season. Consequently he is much interested in the possibility of converting these leaf vegetables during the season when they are very cheap into an imperishable commodity which everybody can buy when fresh vegetables are too expense in the winter season.

Senator Sмiтн of Georgia. The simplest thinker must realize the point of that.

Mr. FaIrChILD. It seems so.

Senator NorRis. Right on that point-I do not know whether you intend to bring it up later-but if you have not, it seems to me appropriate, that it is very desirable, but the practicability of it depends upon its cost. Now, sometime during your talk to us, I would like to have you go into that, if you have made a study of the cost of the machinery, and whether it is practicable for an individual to construct the proper outfit to dry his own product, or whether it ought to be done by having one located in the community to dry for all the people, what it would cost to build, to operate it, etc.

Mr. FAIRCHILD. I can probably answer your question, sir, by giving you a little historical summary of the development of our own investigations, which started with the outbreak of the war. Dr. Alonzo Taylor, now of the Food Administration, who had been through Germany and who had seen the building of these German factories, of which they have now in the neighborhood of 1,000 , for the drying of vegetables, pointed out that there were three kinds 
of drying machines used by the Germans. There were the large class, very expensive affairs running into the hundreds of thousands of dollars; there were smaller plants, community plants, costing as low, as say, $\$ 5,000$ to $\$ 10,000$; and then there were itinerant dryers.

The Chamman. What would the itinerant outfit cost, probably?

Mr. FaIrChILd. When we came to investigate the itinerant, we found there were many features of it which seemed impracticable. The space required for the drying and the time required to dry put it in a very different category from the thrashing machine with which we are very familiar. In other words, a thrashing machine would thrash the product from 100 acres in a rery short time, whereas an itinerant dryer would have to spend the whole summer on that 100 -acre field. So we concentrated our attention, in the first place, on the home dryer, and there were sent out to householders of this country literally millions of descriptions of home dryers, and a great deal of home drying was done, and I have here samples of some of the good home drying products. There is no question but what home drying has its place, but home drying, as I see it, never will and never can supply the city man at the height of the season in the hotels, in the restaurants, and eating places with a standardized product such as he will have to have. Consequently, the question of supplying the cities has naturally come forward, bronght up by commercial concerns, the names of which Mr. Sweet has given you, who have attempted to go into this field that is opening.

In order to make the cost low enough, the plant has to be large enough to utilize fully the orerhead expenses. The costs of drying I can not give you as accurately as I wish I could, nor have I been able to get at the cost of drying as accurately as it should be determined. There are many complicated factors in the situation.

Senator Surтh of Georgia. It necessarily vilries according to the size of the plant!

Mr. FArreinull. Ind the cost of the labor.

Senator sinte of Georgia. The cost of the labor and the cost of the fuel?

Mr. Fairchild. Certainly.

Senator Smrre of Georgia. And filling your plant. and filling it and filling it-continuous work.

Mr. Fairchild. Continuous work.

Senator Smiтh of Georgia. You could put a plant down in the southern part of my State, could you not, where sweet potatoen are very cheap, and you could get in that section such rast quantities of sweet potatce always accessible that you could run a dryer very much more economically than where you could not just take one product and put it through as fast as you could move it. There rou could reduce the cost to the minimum.

Mr. Faircinild. Senator, I have been particularly attracted by the sweet potato possibilities. They are indeed perfectly tremendous. When you consider that the sweet potato requires 15 per cent less potash to grow than the Irish potato, that it requires much less nitrogen than the Irish potato; that it grows on sandy lands, where you can not successfully grow c'orn-it grows in the region of the cheapest labor that we have in the United States: it is a crop wholly understood by the colored man of the Sonth. It is not limited ly the 
factor of the cost of seed, for, as you know, in the second-crop planting cuttings or fragments of the vines are used, and it is only the cost of labor, whereas with the Irish potato you have the cost of the seed. The fact is that you have two crops, not two crops on the same land, but two planting seasons, and the fact that the sweet potato contains less moisture than the Irish potato, making it easier to dry, the further fact is that it contains when dried as high as 21 per cent of cane sugar, making it a sweet product, and, added to that the fact, to which I can testify-I have here the recipes from about 40 people - that it makes a very valuable food, and one equivalent in its calories, or almost equivalent, to that of corn meal, and is suitable for the making of pastries, of cookies, cakes, and all sorts of products of that kind which are easily introduced because they are sweet. If you will look through that list of recipes and comments, Senator, you will find, I think scarcely a criticism or objection to the immediate use of sweet potatoes.

The Chairman. Have they not developed a breakfast food out of sweet potatoes?

Mr. FaIrchim. They have developed breakfast foods and they are very good breakfast foods, indeed. I have not the actual food value of them, but I can readily realize that if they are made entirely of sweet potato they should have approximately the food ralue of corn-meal mush.

Senator Smiri of Georgia. Let me add one thing to your suggestion, that they have raised as high as 700 bushels of sweet potatoes on 1 acre.

Mr. Fatrchild. Yes; immense exceptional yields. It would open the door to the building of a great swect-potato industry in the South.

Coming down to the estimate of cost, the closest estimate I have been able to get from uthers, because, gentlemen, I have not run a factory myself, naturally, was approximately a half cent a pound; that is to say, a bushel of potatoes weighing 60 pounds could be reduced to a meal for approximately 30 cents.

The Chairman. You would have about 10 pounds, approximately?

Mr. FaIRCHILD. And also have 10 pounds of meal.

The Charrman. Doctor, in connection with the first proposition you advanced, if the Government should establish plants in connection with the land-grant colleges, or demonstration plants in some of these States, where vegetables are largely grown, would not that assist your propaganda in the introduction of these products?

Mr. FAIRCHILD. I think it would, but the bill would have to be materially altered and so plain that the funds would not be used up almost immediately in the purchasing of the machinery and especially in the buying of the fresh vegetables for the purpose of drying, with no opportunity to sell those products.

Senator SMrty of Georgia. Doctor, the drying would have to be a revolving fund?

Mr. FAIRCHID. It might have to be a revolving fund.

Senator Surti of Georgia. They ought to have to dry, buy, sell.

Mr. Fatrchmd. As in the present bill, which authorizes the purchase of $\$ 6,000,000$ worth of seeds, along those lines. 
The Charrman. That is a very good suggestion. I did not provide that it ought to be a revolving fund, but I see it ought to be so.

Mr. FaIrchim. Otherwise the money would soon give out.

Senator Norris. They might take toll as they did in the olden times when they took their wheat to the gristmill-bring in the product and take toll of it.

Mr. FAIRChILD. I think the difficulty would be that the man on the farm who brought his product to market would have his own fresh vegetables.

Senator Norkss. Some things, like potatoes, that he could keep he would.

Mr. Falrcindo. That would not make it commercially feasible. We can return to the question of how well these dried vegetables would be liked. I carried on a campaign which I would like to mention in this connection. Assuming that we follow those who are our superiors socially in these matters of food--and I am convinced that the foods we are now growing, many of them at least, became established fashion: through such agencies as the patronage of royalty and the patronage of the Pope in the old days, and similarly to-day I have found by practical experience that with these new vegetables the higher I go up on the social scale the more likelf I am to get people to interest themselves in them. The other's follow their lead just as they do in other fashions.

I got last summer a number of ladies in the Cabinet to taste a number of these dried vegetables to find out whether they would like them, and I have here the testimony from them. There have been given a number of luncheons, or dinners, in which these vegetables have been served just as you would serve fresh regetables, and the testimony indicates that they are very palatable indeed.

Senator Smrt of Georgia. Can these vegetables be had anywhere in Washington? Is there any place where they can be bought on the market?

Mr. Fairchild. That is one of the difficulties; they can not be; and that is where the most serious check in the expansion of the business has taken place.

Senator SмiтH of Georgia. Can these regetables be bought anywhere in Washington in the market?

Mr. Fairchild. That is one of the difficulties. They can not be, and that is where the most serious check and the expansion of the business has taken place. The distributing agencies of any driedvegetable firm must be very large.in order to cover the cities of the country, and unless something unusual is done to attract the public attention to these vegetables they will drag along and be a very long time before they are where people can get to them.

Senator Sмuтн of Georgin. How many plants would you say you could build with $\$ 250,000$-good, big plants?

Mr. Fairchird. It would be very difficult to say. The smallest sweet-potato plant which we have even considered--

Sen:itor Smrtir of Georgia (interposing). That is what I am most interested in.

Mr. FaIrchim (continuing). Would cost about $\$ 5,000$. The drying of the sweet potatoes we figured was a simpler process than any of the other processes. 
Senator Smrtr of Georgia. How many bushels would it turn out a day?

Mr. FaIrchmD. It would turn out, according to the estimate, 500 bushels a day.

Senator Ransperd. It seems to me, if we are going to make a success of this thing and go into it in a big way, we have got to persuade ourselves, first, there will be a material saving to the person who consumes these vegetables. I want to know what studies you have made to show how the grocery bill of a man who eats corn, sweet potatoes, or tomatoes will compare in the future with the present, when you get this thing well worked up. I do not mean in an undeveloped form and as compared not with the present prices but with normal prices before the war. That is an important thing. If we can persuade the poople they are going to get these things cheaper when dried by this process they will certainly take to it, if we go at it right.

Mr. Falrchind. Senator, there is no question about their being cheaper.

Senator Ransdell. Materially cheaper-how much? That is what I want to get at.

Mr. FaIRChIld. I can give you a concrete example. The Walter Reed Hospital wished to test dried cabbages and turnips on 428 men. We furnished them with 4 pounds of cabbage and 5 pounds of turnips, dried. The price of the cabbage fixed by one of the reliable firms was 35 cents a pound, which would make the cost of that calbbage to the hospital $\$ 1.40$, approximately. The cost of the turnips was 30 cents a pound, which would make it $\$ 1.50$. If you look at the prices prevailing to-day, which are those which the hospital has to consider, the cost of 100 pounds of cabbage now is $\$ 3.50$ to $\$ 4$.

Senator Ransdell. It would be the equivalent of these dried cabbage?

Mr. Fairchild. No. The sergeant in charge told me that he normally used about 200 pounds of cabbage. I do not think the portions of cabbage served were as large, but they were certainly half as large, so that at the rate of 100 pounds of cabbage which he would have to buy to take the place of the 4 pounds which was furnished, the difference would still be there between $\$ 1.40$ and $\$ 3.50$.

Senator RANsDell. That is very material saving.

Mr. FaIRchiLd. That is a concrete example; and I went out there inyself and interviewed the men, and Lieut. Baker, who has been very much interested in these things, and the men ate these vegetables and liked them, and there was no question about the economies.

Senator RansDell. What was the saving on the other vegetable? You named one.

Mr. FaIRChILD. With regard to the turnips and the difference in price it would be between $\$ 1.40$ and the price of turnips to-day, which I did not figure out, but which I have here.

And when you consider, Senator, that this is the beginning of a great industry that we are pioneering, it is important, indeed.

Senator RansDeLl. I assume, Doctor, that these comparisons would be even unfair toward the dehydrated product, because they would naturally become very much cheaper in proportion when the people learned the processes and can make them in a large way, is that not correct? 
Mr. Firmchild. The prices I have quoted-that is, 35 cents for the cabbage-includes a considerable percentage for distribution and for advertising. It is estimated at 35 to 50 per cent.

Senator RANSDELL. Those are abnormal conditions which would not occur in normal times, whereas the prices for the, other things are reasonably normal.

Mr. Farrehild. The sil vings would be larger unquestionably on the more succulent vegetables.

Senator RANSDELL. What do you think would be the principal elements of saring to the producer, because I happen to be interested in the producer. I am a producer myself. Where will the saving come in to the producer, first, and then to the consumer in the price that he has to pay?

Mr. FaIromldo. We will take a concrete example in the sweet potato, because I have given rather unusual attention to that. The wastage in the sweet potato business, where the potatoes are kept in banks and in improvised storehouses, varies from 25 to 50 and sometimes as high as 75 per cent. In unusually cold winters, such as the present winter, the regetables are locked up in the ground, and because of this extremely cold weather these banked potatoes are now impossible to get out.

Senator Smrty of Georgia. And you can not rely on getting them as a steady food?

Mr. Fatrchind. You can not do it. Consequently, the installation of dehydration, as I see it, in these sweet potato areas would lead to the utilization immediately from September to November of the sweet potatoes, not only the firsts but the seconds as well, into a nonperishable product. That would stabilize the market. As it is now, while the price per bushel would be much higher, apparently, to the grower, $\$ 1.75$ a bushel would be what he is looking at. How much of his crop does he sell at that price, do you say?

Senator RansDeld. A very small percentage now.

Mr. Farrchind. A very small percentage. The economic result is that we are really paying for sweet potatoes, which have the food value of corn meal, not $4 \frac{1}{2}$ cents, which is the price of a pound of corn meal, but $14 \frac{1}{2}$ cents a dry pound, the price of sweet potatoes at present market price reduced to the dried state of sweet-potato meal. This is because we are marketing only a fraction of the crop.

Senator Smitr of Georgia. We are paying for the loss.

Mr. FAIRChiLd. We are paying for all the loss, and that is very discouraging.

Senator RansDell. And is it not true of very nearly erery other vegetable? The farmer way out in the country can save anything he has got if you have these drying plants in the rarious communities, if it is practicable, I mean, to have them.

Mr. Famrirdid. Yes.

Senator Smith of Georgia. If it is true that by this process you can save the sweet-potato crop, is it not easily possible in the Gulf section to produce sweet potatoes in numbers of bushels equal to the entire corn crop of this country?

Mr. Fairchrmd. I believe it is possible.

Senator Smitr of Georgia. You can produce four or five times as many bushels per acre of sweet potatoes with less work. 
Mr. FaIRChILd. I have not gone into those figures, Senator, and it would be a question of statistics which could be easily letermined. The area is capable of vast extension.

Senator R.ANSDELL. Sweet potatoes do not require any fertilizer, either.

Senator Smith of Georgia. Seven hundred bushels from 1 acre can be produced.

Senator RANSDELL. That is hardly an average. You do not believe Georgia would do that on the average?

Senator SMrTH of Georgia. No; I did not believe it until they brought me a half dozen high-class witnesses who saw it done.

Senator NorRrs. I would believe it, too, if they would bring. me some of the potatoes.

Senator SMith of Georgia. That section also will produce great quantities of Irish potatoes, but they have never been able to save them.

Mr. FaIrChind. The waste is gigantic.

I would like to put into the record a letter which $I$ received from the Royal Horticultural Society of Great Britain, dated January 11. I have kept in touch with this society for years, and I wrote to the secretary, Mr. Wilks, some time ago, asking him for any experience which he had in England which would be of assistance to us here, and I would like to read this portion of his letter:

Then another policy I would like to commend to you would be the setting up in your country of public storehouses, properly organized and equipped, with the conditions which the rarious vegetables require, and including drying and canning apparatus. IVe are now trying to give some attention to this matter in England, and for two reasons: The fixst is that the enormous number of small growers which our food campaign has brought into existence have, most of them, surplus crops which go to waste for want of proper collection and distribution; and the second is that were it known by these small producers that there would be an organized receiving and distributing station for their surplus it would stimulate to an even greatel extent their efforts and their cropping.

Senator RANSDELL. I am curious to ask some of you gentlemen whether these same processes can be applied to meats and fish.

Mr. Horst. I can answer that. They can.

Senator RANSDELL. That is very important. The ptomaine poisoning we suffer from so frequently comes from canned meats and fish.

Mr. Honst. Yes, sir.

Senator RANSDELL. Or does it come from canned vegetables?

Mr. Horst. It comes from the canning process.

Senator RANSDELl. Of fish and oysters-you can not dry oysters, can you?

Mr. Honst. Yes, sir; we do dry oysters. I have samples of dried oysters here.

Senator RansDerc. Let me get clear on that matter about the ptomaine poisoning, because we hear every now and then of persons suffering terribly and dying. Is that eliminated in the process of drying?

Mr. Honst. Dr. Alsberg could probably better answer that than I can.

Dr. Alsberg. Ptomaine poisoning is due to the growth on any foodstuff of certain bacteria, which produce toxic substances. It is 42291-18-3 
usually found in the nitrogenous foods, like meats, fish, and cheese, and anything nitrogenous.

Senator RANSDELL. Not so much on vegetables?

Dr. Alsierg. It is rare on vegetables, although it occasionally does occur, particularly with articles like beans, which, again, are nitrogenous, and occasionally on corn; but it is very unusual in canned vegetables, and when it does occur it is usually on meats or similar products.

Senator RANSDELl. Doctor, would you practically avoid that danger of ptomaine poisoning if we adopted generally this process of drying? Could you answer that question offhand?

Dr. Alsberg. Ptomaine poisoning has not anything to do with the canning process. It is a question of spoiling. If the material that is put into the can is sound and the canning is done properly, then there is no danger. In the same way in drying, if the material is spoiled, then drying will not necessarily make it harmless. The question is whether the material is spoiled or allowed to be spoiled in the process.

Mr. FAIRCHILD. Just one other fact I would like to insert in the record: The 'Tuskegee Institute has been using sweet potatoes in the manufacture of its bread for the institution and for the little village of Tuskegee, which has 500 inhabitants, not connected with the institution, making in all perhaps 2,000 people. This sweet potato is either used in the form of flour or mashed at a rate which means a saving of 200 pounds of flour a day. Dr. Carver, of that institution, came up here with a most remarkable line of samples of sweet-potato flour, which were made with rather primitive tools, but which showed conclusively the possibilities of these sweet-potato products. I have brought some of them here, and, as these testimonials indicate, there is no question about the quality of food value and flaror of this sweet-potato product.

Senator Norris. Before you leave the stand I wanted to ask you a little more about the practical method by which this drying can be brought about. As I understand you the practical method that you advocate is that there should be comparatively large plants established rather than small individual plants.

Mr. FaIrchuLd. As large as the area which they could control would warrant.

Senator Norris. The idea is that if we could establish that it is the practical way of drying these vegetables to have large establishments, then we run at once into the danger of combinations, the same as we have now in meats and in the mills, so that if we could have a small unit that is practicable, perhaps not an individual producer have it, but something near that, we would avoid the danger of control of the output by combinations and monopolies, which we are liable to run into if we must operate in large plants.

Mr. FaIrchiLd. There is no question but that the small plant can turn out a beautiful product. These products you see here are the product of small plants.

Senator NORRIs. How much do they cost?

Mr. FAIRCHILD. I do not know what this particular plant cost, but I know that plants costing $\$ 5,000$ turn out beautiful products. In fact, with some of them it does not require nearly as much of a plant 
as that, and you have all gradations from the home drying, with a primitive plant, which does turn out some very good material, to the superb stuff that is turned out by the $\$ 5,000$ or larger plants.

Senator Norris. How would the small plant be able to compete with the larger ones? Is the unit of cost a great deal larger in a small plant?

Mr. FAIRCHID. I have not gone into that feature of it, but I think it ought to be gone into. The difference would probably be very much in the same ratio as in any other similar operation, such as milling, etc., with the exception that cheap household labor might be employed on the farm with small plants-cheaper than in factories.

The Chairman. Canning plants.

Mr. Fairchild. Canning plants or anything of that kind. The larger the unit, up to a certain point, the more economical the process, depending upon the supply, because, of course, the cost of hauling the vegetables to the mill is one of your important factors. You have got that haul always to consider, and you could not haul a load of sweet potatoes more than, we will say, five or six miles with a team and make it pay.

Senator Sмrтt of Georgia. No. In one of these big fields in South Georgia a man could afford to put up a plant, and with an automobile truck bring the sweet potatoes for 20 miles around to his plant, and they could be bought very cheap; and if there was a certainty of a market they would be raised in enormous quantities.

Mr. FaIRCHID. The market could be had.

Senator SMrth of Georgia: At 50 cents a bushel you can beat 30 cents a pound, I know, with sweet potatoes.

The Chairman. I remember Jefferson once said that whoever introduces a new food plant into a country rendered a great public service. I suppose that would be equally true of a man who devised a new food for an old, such as this sweet potato flour.

Mr. FAIRCHILD. It appeals to one's imagination.

The Chatrman. It would mean a tremendous demand for sweet potatoes.

Senator Smite of Georgia. Of course, I mean b0 cents a bushel right out of the field.

The Chairman. We will now hear you, Dr. Alsberg. Kindly state your name.

\section{STATEMENT OF DR. CARL I. ALSBERG, CHIEF BUREAU OF CHEM- ISTRY, DEPARTMENT OF AGRICULTURE.}

Dr. Alsberg. Carl L. Alsberg, Chief of the Bureau of Chemistry, Department of Agriculture.

The Chatrman. We would like to hear anything you have to say, Doctor, concerning the process of dehydration and the results of it.

Dr. AlsBerg. I have very little to add to the statements which have been made, which are very full and cover the subject, except that it may interest you to know that the matter is one in which the Department of Agriculture has been at work for many years.

When the assignment among the various bureaus of funds under the appropriation made in that food-production bill was under consideration, the Secretary of Agriculture assigned to the Bureau of 
Chemistry a sum of money to carry on work, experimental and propaganda, for this very purpose. The Bureau of Chemistry has been at work on that line, in cooperation with the trade, and we have also purchased two small plants, costing, uninstalled, about $\$ 2,500$ each, one of which is installed in central New York; the other has not yet been delivered, owing to the manufacturing difficulties of getting any kind of machinery delivered at the present time.

Senator RANSDELL. Where is that to be?

Dr. Alsberg. We have not decided where it is to be installed, Senator.

The Chairman. I should think it would be well to locate it in the Southwest; Oklahoma should be selected.

Dr. Alsberg. The matter comes down really to a matter of salesmanship. We are up against the same proposition that any merchant is up against who wishes to put upon the market any new product.

The Chairman. I was just going to ask you, Doctor, whether the scientific work you have spent upon it has not demonstrated to you the feasibility of this process beyond any question of doubt?

Dr. Alsberg. There is no question about it, sir.

The Chatrman. And it is now a practical question of getting the plants installed?

Dr. Alsberg. Yes, sir.

The Chairman. Do you agree about the product being substantially as good as the fresh vegetable?

Dr. AlsBerg. That depends upon what you mean by "as good." It has the same food value. It has not in all cases exactly the same flavor. It is not in all cases exactly the same product, any more than the ordinary dried apple that is on the market is the same product as the fresh apple; but the dried apple is a very useful and valuable food, and has the food value of the apple from which it is made.

So some of these vegetables will be regarded as just the same as the fresh product when they are properly prepared; others will be regarded as bearing the same relation to the fresh product that the ordinary commercial dried apple bears to the fresh apple. But that is an aesthetic matter-a matter of taste and not a matter of value in the diet.

Senator RANSDELL. In substance, they hare stated it correctly, as you understand it?

Dr. Alsberg. Yes, sir.

Senator Norris. I want to ask you about this sample of corn that was dried on the cob. Is that the practical way to dry it? Can you take roasting ears and dry them?

Dr Alsbera. I have had no personal experience with that.

Mr. Gore. It is very easy to dry corn, but not on the cob.

Senator Norris. Have you dried corn on the cob?

Mr. Horst. I have done that, too.

The Chairman. The gentleman who dried that, we will have him make a statement.

Senator NorRIs. Were these samples of corn dried on the cob, as you see them here?

Mr. Hogle. Yes, sir.

Senator Norris. And it is a practical proposition to dry the corn on the cob? Does it not take a great deal longer and require more labor and hot air to do it? 
Mr. HogLe. Not with our process. We do not dry products with hot air.

Senator Norris. You have a different process from those that have been described here?

Mr. Hogle. Yes, sir ; entirely

Senator Norris. All right. I presume you will be on the stand and you can tell us about it later.

The Chairman. Doctor, you think if the Government was to establish these drying plants next to the land-grant colleges and one or two other demonstration plants in the horticultural and gardening States, that it would be of great assistance in securing markets through publicity?

Dr. Alsberg. Yes, sir. The Government can put a thing of this kind into practice at less expense and in less time and more efficiently than interested private parties can. Exactly where each plant should be determined separately in each case.

Tho Charruan. Particularly when the Nation is schooled on food conservation.

Dr. AxsBerg. The department has been trying to get consideration of these products from the public a great many years, and until this present emergency came along we were practically unsuccessful. Now every one is interested, and it may interest this committee to know that through the county demonstration agents of the landgrant colleges who, of course, are working in cooperation with the department, the department has had the drying of vegetables introduced in connection with the canning clubs. Small-scale drying was conducted through the county agents in a very large way last year. The county agents inform me that it has been highly successful, and that they anticipate a very much larger volume of drying this year than last. There were some products we did not understand last year as we do this year. But, on the whole, the field, so far as drying in a small way for the use of the home on the farm is concerned, it is pretty firmly established and is going to grow. It will be promoted in the coming year.

Senator Norris. This gentleman answered about the corn. There is some other method of drying than the one described?

The Chatrman. I expect that is an up-to-date method.

Senator Norris. I wanted to ask the doctor, because he is an expert, whether there are other methods than the one described and that we have been hearing testimony about.

Dr. Alsbera. I do not know of any practical method personally, by which I do not mean to imply that some other method may not be feasible, but I have no knowledge of any other method that is based on any other principle than drying with dry air, either cold dry air or warm dry air.

Senator RANSDELL. Doctor, would it not be entirely practicable for the Bureau of Home Economics in the Department of Agriculture to practically teach people this method?

Dr. AlsberG. You mean home drying?

Senator Ransderc. Yes, sir.

Dr. Alsbera. Yes, sir; it would, and in connection with the county agents.

Senator RANSDELL. And larger plants, if the people wanted to establish them, they could show them? 
Dr. AlsBerg. Yes; that could be done very well.

Senator RANSDELL. You have those agents practically all over the United States. I know down my way the local community contributes a part of the expense of those agents.

Dr. Alsberg. Undoubtedly, the department would have to work through these agents. Of course, not all of these agents-perhaps none of them-are familiar with the operation of the large-sized plant. Such experts in the department as are familiar with them would have to work through the county agents.

Senator RANSDELr. They could be taught from the land-grant colleges readily, I should think.

Dr. Alsberg. Yes. There were one or two questions which came up, such as the question of alcohol.

The Chatrman. Yes.

Dr. Alsberg. Alcohol does not exist as such in appreciable amounts in any of the materials in their natural state from which it is made commercially, Senator. Alcohol is always produced either from sugar or else from starch. Starch is the source of the alcohol, and starch remains in the potato after drying as it was before, so that it is entirely feasible to produce alcohol from dried potatoes.

Senator RansDell. They make it now from sawdust, do they not?

Dr. Alsberg. Yes; but apparently not quite as cheaply as from blackstrap molasses; and, furthermore, the cost from blackstrap molasses is about 16 or 17 cents a gallon, and from sawdust about 22 or 23 cents. Of course, these costs have been shifted by the rising price of molasses, which is away up at the present time.

Then, with reference to costs, I think there has been some confusion. We have thoroughly accurate figures in regard to manufacturing costs for a plant drying, say, 15 tons of potatoes a day-a fairsized commercial plant-which fix the cost of production, including interest and amortization and all the rest of the overhead charges, at a cent a pound, based on the dry product. I should say to produce a pound of dried potatoes would cost a cent a pound plus the cost of the raw materials, whatever they may be. That is a liberal estimate. In some localities it might be considerably less, but that is a perfectly safe estimate for a plant of that capacity. To calculate the cost of the product you would have to add to the 1 cent whatever cost the raw materials would be.

Senator RANSDELL. A cent a pound on dried products?

Dr. Alsierg. Yes; a cent a pound on dried products; that covers just the process-just the process costs-and that includes everything that a manufacturer leeping books in a modern way would charge in.

Senator RANSDELL. That does not include the cost of the package in which the article is put up, does it?

Dr. Alsibrg. No, sir'; that covers labor, interest on the investment, amortization, deterioration, writing off, and all those charges. It does not include any marketing charge; that would vary, of course, immensely according to the manner in which you were going to market it.

The Chatrman. Is there anything further?

Dr. Alsbera. Only one thing. In reference to the question the Senator raised concerning cooking: You can either dry vegetables 
cooked or uncooked-any of these products. They dry quite a little faster, many of them, if they are in the cooked state, because in the process of cooking the little cells of which the tissues of vegetables are composed are burst, and, indeed, that is the object of cooking, that and making things palatable, because when the cells burst the article becomes more digestible. When the cell is burst the water which was in that cell evaporates with greater speed, so that you can dry very rapidly and more cheaply if the article has been cooked. Some articles give you a product which is tastier and of better flavor if cooked first. Sometimes you do not want to cook, but to blanch; that is, to treat it with heat for a very short time. "Blanching" is the technical term the canner uses for a process which is rather scalding than real cooking. That is particularly desirable for vegetables like the potato, the cut surface of which, as everybody knows, will blacken on standing.

That is also true of apples. And this blanching, brief treatment with heat, will interfere with the blackening process, so that there is not any blackening. Of course, the blanching of regetables and fruits is universally practiced by the canner. Some articles he blanches and some things he does not. You can not make any general rule. It depends upon what particular type of product you want to obtain.

Also, it will be necessary in this connection to do a lot of education on the preparation of these products. One of the reasons why they have not established themselves as they should is that not all the romen are willing to experiment and find the best means of cooking. They are dealing with essentially a new material; they have to learn the best technique of handling that material, and that must also be taught, and that is again where the Office of Home Economics will have to be very actire.

I think, Senator, that covers the points I wished to make.

The Chatrman. We are very much obliged to you.

\section{STATEMENT OF MR. H. C. GORE, BUREAU OF CHEMISTRY, DEPARTMENT OF AGRICULTURE.}

The Charrman. Kindly state your full name, Doctor.

Mr. Gore. H. C. Gore, of the Bureau of Chemistry.

The Chairman. Doctor, we will be glad to have any statement you desire to make on this subject.

Mr. Gore. So much has been said that I do not know what further can be said to amplify the subject. We feel it is rel'y necessary that the Government standardize the industry and save it the long period of uncertainty that we find has existed in the past with such industries as canning. Mr. Sweet mentioned the large number of small drying plants which are now started up, and stated, I believe, that a number of those plants were not producing a product of very good quality. If the public gets a hold of any large quantity of such material, dried products may get a bad reputation, which they do not merit, and we feel that if the Government can take hold of the drying right now we can do a great deal of standardizing of products and make them what they really are, if reasonably treated. and so save the industry perhaps years of development. 
The Chairman. Get them started right?

Mr. Gore. Yes, sir.

The Chairman. Something like Denmark has done in her government marketing of butter and wheat.

Mr. Gore. The history of the drying industry bears that out. A good many products have been put on the market which have not held up well, and they have found slow sale. You can find at the present time, especially in the sporting goods stores, that they do not move. Our bureau is investigating the causes of that, and the remedies.

The Chatrmax. It would be possible to work out a plan from the plant methods of standardization so as to create that result and obviate the difficulties that would follow unstandardized stuff being put on the market.

Mr. Gone. We are in position, at the present time, to give a good deal of information along that line, and will have more a little later.

The Chairmax. Do you know how many different processes there are of dehydration?

Mr. Gort. The principal process is simply drying the products in a current of moving air in condition to absorb moisture. Once you have said that you covered the vast majority of drying processes.

The Chatrmax. Everything else is incidental to that, is it?

Mr. Gore. Yes, sir.

Senator Norris. This gentleman was speaking of some other process. I would like to hear from him.

\section{STATEMENT OF MR. CHESTER F. HOGLE, REPRESENTING POSTUM CEREAL.}

The Chairman. What is your present business, Mr. Hogle.

Mr. Hogle. I am in the lumber business, principally, also the sugar business, and I represent the Postum Cereal, the Purity Oats Co., and a number of similar concerns.

The Charrman. We would ge glad to hear anything you might care to say on the subject of dehydration.

Mr. Hogle. I have given a great deal of thought and study to the matter, on account of the tremendous needs that this country is facing, not only on behalf of the Army and Navy, but for the populace as well, from the standpoint of supplying sufficient nutritive foods promptly and in palatable form. Last July the gentleman who is present here in the room brought me at my office in Chicago a process which he claimed at that time, and which I have since satisfied myself of, as being the opposite of every other method of dehydration or drying of fruits, vegetables, meats, and fish, which has been employed up to this time, and the results of this process as compared with the goods produced by other methods is manifest in the quality, in the appearance and color and in the flavor. So far as dehydration is concerned in this country, we have. comparatively speaking, practically nothing.

Being largely identified in the beet sugar industry and having been 20 years engaged in it, we are used to figuring in thousands of tons. At this time on this present crop of 1917-18, we have raised and manufactured in this country in from 90 to 120 days approximately $7,000,000$ tons of bects. I have been down here since the 12th 
of November with these samples. Probably some 200 Government officials have viewed them at the Lafayette. Hotel, and many of them have taken them home and tried them, and without exception they have stated they could not be distinguished from fresh vegetables.

And now, for our present needs under war conditions, as an individual, and $\mathrm{my}$ associate, Mr. Hulbert, felt the same way, our first duty was to the United States Government, and with that in view we came to Washington with these samples and tendered the free use of this process to the Government, together with my services, without remuneration for the term of the war.

The Chairman. Is it a patented process, Mr. Hogle?

Mr. Hogwe. Yes, sir. For the erection of sufficient capacity, first, to take care of the entire needs of the Army and Navy, after which plants could be erected as desired throughout the country to take care of the needs of the civil population. The matter has been carefully considered by various departments. The conclusion has not yet been reached.

Senator Norris. How long have you been at it?

Mr. Hogle. I arrived here the 12 th of November. My first proposition was that the Government should build the plants and operate them themselves to produce these products. I was then requested to ascertain on what basis I could secure the plants, and what the capacity necessary would be; what would be the cost of the plants, and what would be the cost of the products, and in what length of time those plants could be put into operation.

With this in view I took the matter up with our engineers in Chicago, and they advised that they could supply f.o o. b. cars in Chicago sufficient capacity to feed 1,000,000 men within 90 days from the day they received the order, and that those plants could be put into operation within 60 days from arrival at chosen destinations where sufficient green material was available. On the present basis of 20 ounces per man per day, which is the Government ration, all the Government requires to feed $1,000,000$ is a daily capacity of 650 tons, which is only about equal to the capacity of our smallest beet-sugar plant, which plants range in capacity from 500 tons to 1,000 tons green per day. Our greatest need in these products for the civil population is in the thickly populated districts, where green vegetables are available temporarily and usually at prices beyond the reach of the ordinary consumer. Now, with meat and eggs at present prices and green vegetables practically. unobtainable to the average man, he is in pretty bad shape, and it is my understanding that the Government figures to-day that we are now losing approximately 54 per cent of our fruits and vegetables in this country that come to maturity, and they are never available, for either human or animal consumption, from such causes as rot, poor transportation facilities, poor marketing facilities, undesirable markets, market conditions, etc. In Germany, I am informed, on July 1, 1916, there were 861 dehydrating plants in operation. I quote from the New York Sun of December 9 [reading]:

In June, 1914, there were 480 dehydrating plants in Germany producing annually about a quarter million pounds of potatoes alone. In a food conservation campaign organized at the time of Germany's first declaration of war 246 new dehydration plants were added, 190 of which were aided by Government funds. 
That, gentlemen, is the secret of Germany's self-containment in the matter of foods throughout this war and at the present time, and, as previously stated, we have practically no capacity in this country to-day, viewing the situation broadly.

Senator NoRRIs. Is this system of yours a dehydrating process?

Mr. Hogle. No, sir; a curing process. The term "dehydrating" actually means the removal of water, but our process is not a dehydrating process in the generally accepted meaning of that term.

Senator NoRRIs. Is your process used in Germany?

Mr. Hogle. No, sir.

Senator NorRIs. It is a new process here?

Mr. Hogle. A new process.

Senator NoRRIs. Of these samples here, which are yours?

Mr. HogLe. All these samples here are ours.

Senator Norris. At this end of the table here [indicating].

Mr. Hogle. Yes, sir.

Senator Norris. Can you tell us something about the cost and practicability to put up a plant?

Mr. Hogle. Yes, sir. In the matter of costs, the British Government recently placed orders for $400,000,000$ pounds of fine-cut fried potatoes, which are cut in small squares, and available only for soup, at a price, varied through this coming year, if I understand it, of $25,27 \frac{1}{2}$, and 30 cents per dried pound, which, if equally distributed, would give you an average cost on the $400,000,000$ pounds of $27 \frac{1}{3}$ cents per pound. In figuring the cost of feeding $1,000,000$ men, we would save the Government in actual cash against what the British Government has already paid-I presume you would like the exact figures- $\$ 10,579,433.33$.

The Chairman. What is that?

Mr. Hogre. That is the saving on six months' supply for $1,000,000$ men at the price the British Government has already paid.

The Chairman. That is, you think it could be worked on that basis so as to make that saving?

Mr. Hogle. We know it could.

Senator Norris. What products?

Mr. Hogue. Applied only to potatoes.

Senator Norris. Just to potatoes?

Mr. HogLe. We have calculated it, because the Army ration may be 100 per cent, and, in any event, not less than 70 per cent; so that is the thing we are particularly interested in.

In addition to that, the Surgeon General's Office, on inquiry, advised me that as near as he could estimate it, it took two men all day to prepare sufficient potatoes and such other vegetables as may be obtainable to feed 100 men. Therefore, figuring on the basis of $1,000,000 \mathrm{men}$, the continuous daily labor of $20,000 \mathrm{men}$, or 2 per cent, of your Army could be released for other duty by the use of these products. In addition to that, you would save from 60 to 75 per cent of the freight room and freight charges. On the six months' supply that saving in freight room would be 100,000 tons.

Senator Norris. You are comparing the food prepared by the drying process and by your process.

Mr. Hogle. No, sir.

Senator NorRIs. You mean it would not take as much storage room? 
Mr. Hogue. It takes only 25 per cent as much storage room.

Senator Norris. And you would release men who prepare the food by having it already prepared?

Mr. Hogle. Yes, sir; by having it entirely prepared. You can see they are all ready to cook-peeled and sliced and ready to cookand when they are cooked they can not be distinguished from fresh products by anyone.

Senator NorRIs. I wish you would tell a little more about the process. I am curious to know about it. I confess it is new to me.

Mr. Hogle. It is new, and the difficulties we have met have been principally on account of its being new. We are facing the same skepticism that confronts every new idea, which confronted the telcphone and wireless and everything else.

Senator NorRIs. It is not a drying process?

Mr. Hogre. No, sir; it is a curing process.

Senator Norris. The effect of it is about the same?

Mr. Hogle. No, sir.

Senator Norris. Take this potato. What has happened to that? You have taken the moisture out of it?

Mr. Hogle. That is very true.

Senator Norris. That is the same as they do when they dry it.

Mr. HogLe. I know; but the results are entirely different when the moisture is removed by this process as against any other process known. In fact, our patent attorneys have advised us, after conferring with the Commissioner of Patents, that this is the reverse of every other process of drying that has ever been attempted, and the results speak for thems ${ }^{\circ}$ ives.

Senator NorRIs. Take this sample of corn on the cob here.

Mr. Hogce. Yes, sir.

Senator NorRis. That is cooked, all ready to eat, is it not?

Mr. Hogle. No, sir; that is raw corn. There is the cob right alongside of it; that is, the cob for that one in the bottle-the same kind of corn.

Senator Norris. Yes; that has been in water in this can?

Mr. HocLe. That is just water, with benzoate of soda to keep it sweet; that is all.

Senator Norris. And the finished product by your process-

Mr. Hogle (interposing). Is raw, ready to cook.

Senator NorRIs. Yes; but it is not this size.

Mr. HogLe. When we get through with it it is like that. When you buy it as a consumer, you take it and soak it, and when it soaks. back to actual normal size you take it and boil it.

Senator Norris. This I hold in my hand is the finished product?

Mr. Hograe. Yes, sir.

Senator Norris. And this in the can is the finished product, soaked?

Mr. Hogle. Yes, sir.

The Champins. And the shrinkage is just about the same as related here?

Mr. Hogre. The Government figures show, based on some 4,000 tests, that the shrinkage is from 60 to 94 per cent; for instance, cauliflower. 94 per cent; potatoes, 62 per cent.

Senator Norris. The space occupied by the finished product is the same space that would be occupied by the product if dried, is it not? 
Mr. Hogre. Oh, yes; there is no saving in space between our products, so far as space is concerned, and any other dried product.

Senator Norris. But, as I understand it, you claim that the process does it more economically and cheaper than the drying process?

Mr. Hogle. Yes, sir. Not only that, but that they can not be distinguished from the fresh products either as to color, flavor, or food value.

Senator Norris. Then the process must be less expensive, I take it, than the other?

Mr. Hogle. It is.

Senator NorRIs. Is it a process that would be practicable for an individual, for instance?

Mr. Hogle. Not for individuals; no, sir; at least we have not tried to work it out to that extent. Our first thought, as I explained, were the needs of the Army and Navy; the second is the erection of large plants at convenient points based on convenient raw material.

The Cimiracax. What do you estimate those plants to cost, ranging between what figures?

Mr. Hogle. We have a price which we have submitted on capacity sufficient to take care of the requirements of the Army and Navy.

The Chalrmax. How many plants does that involve?

Mr. HocLe. It just depends on whether you want to start in a number of places or put them all in one place.

The Chummax. What I want to get at is what would one of the units costs, whether all in one place or distributed.

Mr. Hogle. One of our units with 1,000 pounds capacity a day, f. o. b. Chicago, would cost $\$ 750$.

Senator Norris. Does it require any technical knowledge to operate, or anything of that kind?

Mr. Hogle. No, sir.

Senator Nornis. How old is the patent?

Mr. Hogle. Just this year. It is entirely new, but those men have had a hard time.

Senator Norris. What I would like to get at is, for instance, if it were a practical proposition after the war was orer. so that plants that are not expensive could be established in various localities. Of course, if you have to ship the product before preparing it long distances then you interfere, of course, with its cost, increase it greatly and make it less practicable.

Mr. Hogidi. Our process is entirely elastic in that respect, because we can erert capacity with full efficiency of from 1.000 pounds green per day.

Senator Norris. When you siid a factory wonld produce 1,000 pounds a day could be erected for $\$$ Tisu-

Mr. Hogie (interposing). Could not be erected.

Senator Noris. The machinery would cost that?

Mr. Hogre. Tes, sir.

Senator Norris. Does that mean 1,000 poumls dried or green?

Mr. Hogre. No; that does not mean green. Fou can place those plants at any desired locality in units of from 1.000 pounds to 2.000 pounds a diy if you care to.

Senator Normis. Your patent is on the machinery?

Mr. Hogle. On the process. 
Senator Norris. Is it for sale? I mean would you put up a plant for anybody who wanted you to put one up, and allow them to use the process if you erect the plant for them?

Mr. Hogle. We came down here to tender the use of this to the Government first. I have kept the matter entirely in my own hands until the Government could say whether they cared to avail themselves of my offer or not. That was done on the advice of Mr. Harry A. Wheeler, food administrator of Illinois.

Senator Norris. You have not decided yourselves then what you are going to do, or how you are going to operate it?

Mr. Hogle. We have formulated plans to operate it commercially, and just as soon as the Government says whether they want to do anything with it. If they say they do, my services are at their command. If they do not, I have ample means at my command to proceed commercially.

Senator NorrIs. And then you will establish plants at various places?

Mr. Hogle. Yes, sir.

Senator Norris. Can you describe the process to us?

Mr. Hogre. I would prefer that you get a copy of the patent and read it, and then you can get it clearly yourself.

Senator NorRIs. You could tell us in general, ordinary language, in a few words, so we would understand it better than if we read the patent.

Mr. Hogle. There is one objection to that. While it is patented process and the copy of the patent is available, if the notes of the stenographer here are for publication or for public circulation, don't you think it would be rather unwise to disclose a method of this kind for general information?

Senator Norris. I am not asking you to disclose any information that is secret, or anything of that kind.

Mr. Hogle. There is nothing secret about it.

Senator Norris. If it is patented you would not run any risk in telling all about it.

Mr. Hogle. There is no risk in telling about it, and it is all in the patent, I mean to say, not if these remarks can be circulated.

Senator NorRIs. They can be, of course; they will be published.

Mr. Hogle. I refer to the unwisdom of circulating particular information about something that is for our benefit.

Senator Norris. I should think you would be glad to have it circulated and advertised.

Mr. Hogle. I know, but should we make this process available to our enemies as freely as to ourselves?

Senator NorRIs. Not if it is patented.

Mr. Hogle. What is to prevent the process, for instance, from getting to Germany? This is far in advance of anything that they are doing. If you wish me to tell what it is, I am perfectly willing to do so.

Senator Norris. No; I would not want it to get to Germany.

Mr. Hogle. That is the risk; that is the only reason I hesitate; and if you would care to call at the Lafayette Hotel you can see the full display of these products. Now, these restored samples here scarcely represent the products when freshly restored, because they 
have been soaking and subjected to the sunlight. But we have freshly restored ones at the Lafayette Hotel, and if you have cooking facilities, we would be delighted to furnish you with such products, and, then, you can satisfy yourself.

Senator NorrIs. I have; and my wife does the cooking.

Mr. Hogue. That is fine.

Senator Norris. And I would be glad to, as I took some of these other samples, I would be glad to take home some of yours and have my wife try them.

Mr. Hogle. I will either send them to you, or, if you will call at the hotel, I will be pleased to explain this process and give you such products as you care to select, because we have a large line there.

The Chairman. Unless there are further questions the committee desires to ask any of these gentlemen, we will close the hearing.

(Thereupon, at 5.25 o'clock p. m., the committee adjourned to meet at the call of the chairman.) 



